\title{
Beryllium-7 and Lead-210 are Associated with an Increase in the Arctic Oscillation: Evidence from Atmospheric Aerosols in a Remote Tropical Region in East Asia
}

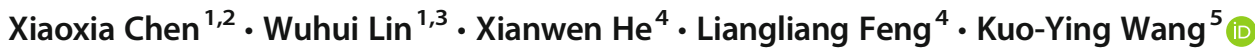 \\ Received: 14 November 2020 / Revised: 17 February 2021 / Accepted: 18 March 2021 / Published online: 9 April 2021 \\ (C) The Author(s) 2021
}

\begin{abstract}
The Arctic Oscillation (AO) accounts for a large fraction of recent decadal climate trends in Northern Hemisphere (NH) high latitudes. In East Asia, an elevated AO index (AOI) was associated with warmer temperatures in middle- to high-latitude regions, colder temperatures over low-latitude regions, and elevated ozone intrusion from the stratosphere. Elevated beryllium- $7\left({ }^{7} \mathrm{Be}\right)$ is produced in the stratosphere. Few studies have discussed the relationship between ${ }^{7} \mathrm{Be}$ and the AO. Here, we identify the AO signature in ${ }^{7} \mathrm{Be}$ and lead $(\mathrm{Pb})-210$ observed at a tropical ambient monitoring site in Nanning $\left(22.8^{\circ} \mathrm{N}, 108.5^{\circ} \mathrm{E}\right)$ during the December 2014-December 2017 period. Our results show that the ${ }^{7} \mathrm{Be}$ and ${ }^{210} \mathrm{~Pb}$ concentrations are positively and significantly correlated with the AOI $(P<0.01)$. These results show that elevated ${ }^{7} \mathrm{Be}$ and ${ }^{210} \mathrm{~Pb}$ are associated with an increase in the AOI, reflecting air masses originating from $\mathrm{NH}$ high latitudes and vertically from the high-latitude upper troposphere and lower stratosphere regions to tropical latitudes in East Asia. These results have been verified with ozonesonde data without seasonality and with two meteorological data sets. Our results are also confirmed by observational data over the Pacific regions. We conclude that the $\mathrm{AO}$ exerts impacts over the tropical regions in East Asia, and ${ }^{7} \mathrm{Be}$ can be used as a tracer to track the impacts of the AO.
\end{abstract}

Keywords Beryllium- $7 \cdot$ Lead-210 $\cdot$ Arctic oscillation $\cdot$ Atmospheric aerosols $\cdot$ Nanning

\section{Introduction}

The Arctic Oscillation (AO) is the primary reason for the interannual variability in the troposphere and lower stratosphere. The AO affects the extratropical surface climate variability in the Northern Hemisphere (NH), especially during

Responsible Editor: Jong-Seong Kug.

Kuo-Ying Wang

kuoying@mail.atm.ncu.edu.tw

1 School of Marine Sciences, Guangxi University, Nanning 530004, China

2 College of Ocean and Earth Sciences, Xiamen University, Xiamen 361102, China

3 Guangxi Laboratory on the Study of Coral Reefs in the South China Sea, Nanning 530004, China

4 Radiation-Environment Management and Monitoring Station of Guangxi Zhuang Autonomous Region, Nanning 530222, China

5 Department of Atmospheric Sciences, National Central University, Chung-Li District Taoyuan City, Taiwan winter and spring (Thompson and Wallace 2000; Hurrell et al. 2003). Its variability is commonly manifested by a sealevel pressure (SLP) difference between stations in the Azores (Portugal) and Iceland (Thompson and Wallace 1998; Cutlip 2000; Thompson and Wallace 2000; Thompson and Wallace 2001; Thompson and Lorenz 2004). The AO initially emanates from the stratosphere and ultimately alters surface weather, subsequently affecting the temperature and precipitation in most $\mathrm{NH}$ areas. Hence, the AO is closely related to the frequency and intensity of extreme weather events (Thompson and Wallace 1998; Thompson and Wallace 2000; Thompson and Wallace 2001; Black 2002; Thompson and Lorenz 2004).

In particular, the $\mathrm{AO}$ accounts for a large fraction of recent decadal climate trends in high northern latitudes (Hurrell 1995; Thompson et al. 2000). Thompson et al. (2001) found that in recent decades, the continuous high trend of the North Atlantic Oscillation (NAO, which can be viewed as an $\mathrm{AO}$ subset (Jevrejeva and Moore 2001)) is an important reason for winter warming in the $\mathrm{NH}$. In East Asia, as the winter AO index increases from low to high, the temperatures in the middle- and high-latitude regions of the Asian continent 
become warmer, the low-latitude regions become colder, and vice versa (Wu and Wang 2002; Gong et al. 2001; Jeong and Ho 2005; Chen et al. 2013).

Beryllium-7 $\left({ }^{7} \mathrm{Be}\right)$ is a sensitive indicator of stratospheric air intrusion into the troposphere and this radionuclide is classically applied in the stratosphere-troposphere exchange (STE) (Dibb et al. 1992; Bonasoni et al. 1999, 2000a, b; Cristofanelli et al. 2007, 2006, 2009). In contrast, ${ }^{210} \mathrm{~Pb}$ has been used as a continental tracer of air masses and long-range transport of chemical constituents (derived from continental sources) (Balkanski et al. 1983; Turekian et al. 1983; Baskaran 2011). The cosmogenic radionuclide ${ }^{7} \mathrm{Be}$ (its halflife is 53.3 days) is produced by high-energy spallation interactions between galactic cosmic-ray (GCR)-produced neutrons and protons (secondary particles) and atmospheric nuclei (primarily nitrogen, oxygen and argon) (Lal and Peters 1967; UNSCEAR 2000; Usoskin and Kovaltsov 2008; Papastefanou 2009; see Fig. S1).

Increased ozone over much of Asia results from the positive phase of the AO combined with changes in the stratosphere-troposphere exchange (STE; Holton et al. 1995; Wang et al. 2002; Wang and Kau 2015) that are responsible for the correlation pattern between ozone and $\mathrm{AO}$ at $800 \mathrm{hPa}$ (Lamarque and Hess 2004). This study shows that the tropospheric ozone concentration over Asia is affected by the intrusion of stratospheric ozone. Similar to air containing elevated ozone levels in the stratosphere, an elevated ${ }^{7} \mathrm{Be}$ level occurs in the stratosphere. Hence, ${ }^{7} \mathrm{Be}$ is a stratospheric tracer that can be directly or indirectly influenced by the AO.

Similar to ${ }^{7} \mathrm{Be}$, ozone from the stratosphere is considered an indicator of the Arctic Oscillation (Thompson and Wallace 2000; Lamarque and Hess 2004; Dibb et al. 1992). However, few studies have discussed the relationship between ${ }^{7} \mathrm{Be}$ and the Arctic Oscillation. It is worth discussing whether ${ }^{7} \mathrm{Be}$ can be used as a tracer to track the Arctic Oscillation and whether the signal of the Arctic Oscillation can be discovered through aerosol data in the tropics to study the mechanism of climate teleconnection. Production of ${ }^{7} \mathrm{Be}$ is the highest in the stratosphere $(75 \%)$, while the remaining part $(25 \%)$ is produced in the upper troposphere (Johnson and Viezee 1981; UNSCEAR 2000; Usoskin and Kovaltsov 2008). ${ }^{7}$ Be production increases with altitude and geomagnetic latitude and is also associated with the 11-year solar cycle that modulates cosmicray penetration through the Earth's magnetic field (Lal and Peters 1967; Bhandari and Lal 1970; Dibb et al. 1992; UNSCEAR 2000; Usoskin and Kovaltsov 2008). The polar stratosphere experiences the highest production rate, and the tropical lower troposphere exhibits the lowest production rate (Feely et al. 1989).

${ }^{210} \mathrm{~Pb}$ (with a half-life of 22.3 years) and its progeny polonium, (Po)-210, originate from the naturally occurring radionuclide uranium, (U)-238, in the environment; this can produce radium, (Ra)-226, and radon, (Rn)-222, which are precursors of lead, $(\mathrm{Pb})-210\left({ }^{210} \mathrm{~Pb}\right)$. Due to the continental origin of ${ }^{222} \mathrm{Rn},{ }^{210} \mathrm{~Pb}$ is considered a tracer of air masses with continental origins (Balkanski et al. 1983; Turekian et al. 1983; Baskaran 2011). ${ }^{222} \mathrm{Rn}$ emanates primarily from rocks and minerals in the crust. Therefore, the spatial variability of ${ }^{210} \mathrm{~Pb}$ is strongly dependent on the geographical types of terrestrial surfaces, and the ${ }^{222} \mathrm{Rn}$ flux from the ocean is negligible (San Miguel et al. 2019).

${ }^{210} \mathrm{Po}$ and ${ }^{210} \mathrm{~Pb}$ nuclides are concentrated in the air over inland cities and industrial areas because of artificial sources, such as industrial mining, automobile exhaust and construction dust (burning of coal, use of phosphate fertilizers, car exhaust, and fires) (Jaworowski et al. 1980; Hotzl and Winkler 1987; Lozano et al. 2013). Once formed in the air, ${ }^{7} \mathrm{Be},{ }^{210} \mathrm{~Pb}$, and ${ }^{210} \mathrm{Po}$ are rapidly combined with submicron-sized aerosol particles (Maenhaut et al. 1979; Bondietti et al. 1987; Papastefanou 2009). Hence, their concentrations in air are similar to those of aerosol particles and depend on atmospheric transport and wet and dry removal (Papastefanou and Ioannidou 1995; Baskaran 2011).

Because of the different sources of the two radionuclides, simultaneous measurements of ${ }^{7} \mathrm{Be}$ and ${ }^{210} \mathrm{~Pb}$ and their ratios can be implemented to identify the origin of air masses (Graustein and Turekian 1996; Bonasoni et al. 2000a, b; Zheng et al. 2005) and to study the vertical motion of air masses and convective activity in the troposphere (Brost et al. 1991; Koch et al. 1996; Lee et al. 2004; Tositti et al. 2004; Lee et al. 2007). Moreover, temporal and spatial variations in this ratio reflect both vertical and horizontal transport in the atmosphere (Koch et al. 1996; Baskaran 2011). Due to their halflives $\left(22.3\right.$ years for ${ }^{210} \mathrm{~Pb}$ and 53.2 days for $\left.{ }^{7} \mathrm{Be}\right)$, both natural radionuclides can persist long enough for longrange transport in the atmosphere (Zhang et al. 2015; Grossi et al. 2016; San Miguel et al. 2019).

In this paper, we report a three-year (2014/10-2017/12) study conducted on the abundance of ${ }^{7} \mathrm{Be},{ }^{210} \mathrm{~Pb}$, and ${ }^{210} \mathrm{Po}$ in the surface air over tropical urban site Nanning, China $\left(22.8^{\circ} \mathrm{N}, 108.5^{\circ} \mathrm{E}\right)$. In addition, the interrelationship among these nuclides and a suite of related environmental factors, such as the AO, precipitation, cosmic rays, and earthquakes, are also investigated. This paper adopts the Hybrid Single-Particle Lagrangian Integrated Trajectory (HYSPLIT) model to calculate the origins of air masses reaching the Nanning sampling site, compares the Nanning results to Environmental Measurements Laboratory (EML) observations, and applies a regression model to study the correlations among the variables of AOI, precipitation, air mass origin (latitude, longitude, and altitude), ${ }^{7} \mathrm{Be}$, and ${ }^{210} \mathrm{~Pb}$. 
Table 1 Abundances of ${ }^{7} \mathrm{Be}$,

${ }^{210} \mathrm{~Pb}$, and ${ }^{210} \mathrm{Po}$ in ambient aerosols over Nanning

\begin{tabular}{|c|c|c|c|c|c|}
\hline Code & Start time* & Finish time* & $\begin{array}{l}{ }^{210} \mathrm{Po}(\mathrm{mBq} / \\
\left.\mathrm{m}^{3}\right)\end{array}$ & $\begin{array}{l}{ }^{210} \mathrm{~Pb}(\mathrm{mBq} / \\
\left.\mathrm{m}^{3}\right)\end{array}$ & ${ }^{7} \mathrm{Be}\left(\mathrm{mBq} / \mathrm{m}^{3}\right)$ \\
\hline 1 & $09.10 .2014, /$ & 10.10.2014, / & 0.55 & 3.92 & 12.7 \\
\hline 2 & $04.11 .2014, /$ & $05.11 .2014, /$ & 0.52 & 1.62 & 9.09 \\
\hline 3 & 08.12.2014,09:19 & 09.12.2014,10:00 & 0.3 & 3.63 & 10.3 \\
\hline 4 & $05.01 .2015,10: 38$ & $06.01 .2015,10: 39$ & 0.48 & 0.71 & 6.08 \\
\hline 5 & 02.02.2015,09:28 & $03.02 .20150,9: 40$ & 0.34 & 3.3 & 1.1 \\
\hline 6 & $04.03 .2015,08: 25$ & 05.03.2015,08:35 & 0.84 & 1.9 & 3.36 \\
\hline 7 & $13.04 .2015,10: 30$ & $14.04 .2015,10: 30$ & 0.9 & 2.13 & 9.37 \\
\hline 8 & 04.05.2015,09:10 & 05.05.2015,09:48 & 0.76 & 0.83 & 1.48 \\
\hline 9 & $16.06 .2015,08: 58$ & 17.06.2015,09:05 & 0.8 & 0.88 & 1.03 \\
\hline 10 & 22.07.2015,09:04 & $23.07 .2015,10: 18$ & 0.59 & 0.36 & 0.9 \\
\hline 11 & $10.08 .2015,09: 45$ & 11.08.2015,09:50 & 0.74 & 0.77 & 1.97 \\
\hline 12 & $23.09 .2015,09: 27$ & $24.09 .2015,10: 24$ & 0.52 & 1.58 & 2.61 \\
\hline 13 & 19.10.2015,10:08 & $20.10 .2015,10: 23$ & 0.69 & 2.43 & 7.56 \\
\hline 14 & 02.11.2015,16:07 & $03.11 .2015,16: 46$ & 0.61 & 2.63 & 4.91 \\
\hline 15 & $16.12 .2015,10: 51$ & $17.12 .2015,14: 57$ & 0.72 & 2.79 & 7.83 \\
\hline 16 & 19.01.2016,10:39 & $20.01 .2016,11: 19$ & 1.19 & 3.12 & 8.41 \\
\hline 17 & $16.02 .2016,10: 32$ & $17.02 .2016,10: 45$ & 0.43 & 1.26 & 8.5 \\
\hline 18 & 01.03.2016,10:05 & 02.03.2016,16:07 & 1.16 & 1.67 & 8.98 \\
\hline 19 & $06.04 .2016,14: 50$ & 07.04.2016,15:07 & 0.34 & 0.92 & 4.66 \\
\hline 20 & $03.05 .2016,10: 13$ & $04.05 .2016,10: 35$ & 0.24 & 2.47 & 3.47 \\
\hline 21 & $27.06 .2016,09: 50$ & $28.06 .2016,10: 11$ & 0.19 & 0.23 & 0.84 \\
\hline 22 & $18.07 .2016,08: 40$ & $19.07 .2016,08: 52$ & 0.31 & 0.34 & 2.47 \\
\hline 23 & $08.08 .2016,11: 35$ & 09.08.2016,11:12 & 0.8 & 0.83 & 1.1 \\
\hline 24 & 18.09.2016,16:00 & 19.09.2016,16:20 & 0.67 & 1.28 & 3.55 \\
\hline 25 & 09.10.2016,09:01 & $10.10 .2016,08: 56$ & 0.87 & 1.71 & 3.52 \\
\hline 26 & $14.11 .2016,11: 10$ & $15.11 .2016,11: 35$ & 0.18 & 0.61 & 0.78 \\
\hline 27 & $07.12 .2016,10: 42$ & $08.12 .2016,10: 32$ & 1 & 1.62 & 9.66 \\
\hline 28 & 03.01.2017,11:50 & 04.01.2017,12:05 & 0.869 & 2.309 & 5.76 \\
\hline 29 & $13.02 .2017,10: 38$ & $13.02 .2017,10: 38$ & 0.515 & 1.412 & 6.55 \\
\hline 30 & $02.03 .2017,15: 52$ & 03.03.2017,15:08 & 1.679 & 2.622 & 7.69 \\
\hline 31 & $17.04 .2017,10: 56$ & $18.04 .2017,11: 24$ & 0.393 & 0.854 & 1.21 \\
\hline 32 & $03.05 .2017,17: 15$ & $04.05 .2017,17: 22$ & 0.223 & 1.129 & 2.14 \\
\hline 33 & $20.06 .2017,11: 00$ & $21.06 .2017,09: 45$ & 0.625 & 0.669 & 0.484 \\
\hline 34 & $20.07 .2017,09: 45$ & 21.07.2017,09:15 & 0.227 & 0.238 & 0.765 \\
\hline 35 & $07.08 .2017,11: 25$ & 08.08.2017,11:16 & 0.517 & 0.372 & 0.743 \\
\hline 36 & $29.09 .2017,16: 35$ & $30.09 .2017,17: 15$ & 0.235 & 0.265 & 0.387 \\
\hline 37 & $30.10 .2017,09: 00$ & $31.10 .2017,17: 05$ & 0.905 & 1.314 & 0.781 \\
\hline 38 & 17.11.2017,16:10 & 19.11.2017,11:50 & 0.172 & 0.298 & 0.649 \\
\hline 39 & $09.12 .2017,20: 12$ & $10.12 .2017,19: 33$ & 0.538 & 2.054 & 0.646 \\
\hline
\end{tabular}

*The local time of Nanning is given in the following format: DDMMYY, HH:MM (day, month, year, hour, minute; 08.12.2014 is read as 8 December 2014)
In this work, we show that air movement in the polar stratosphere affects the tropical troposphere based on observations of radioactive materials near the ground in the tropics. These chemical observations further strengthen the dynamic aspects of stratosphere-troposphere coupling processes (Hoskins et al. 1985). In this paper, we consider the AO as the main mechanism driving air movement variations in the stratosphere-troposphere coupling system. We adopt ${ }^{7} \mathrm{Be}$ as a tracer for the stratosphere and ${ }^{210} \mathrm{~Pb}$ as a tracer for the troposphere. With this framework, this work addresses the following issues. (1) A significant correlation has been observed between ${ }^{7} \mathrm{Be}$ and $\mathrm{AOI}$, proving that the impact of the $\mathrm{AO}$ from 
the NH polar stratosphere can be observed near the surface of the tropical troposphere. (2) The good linear correlations between ${ }^{7} \mathrm{Be}$ and ${ }^{210} \mathrm{~Pb}$ indicate that the stratosphere and troposphere are coupled.

\section{Data and Methods}

\subsection{Observational Data}

\subsubsection{Site Description}

The sampling site is an automatic environmental station in Nanning city, China $\left(22.8^{\circ} \mathrm{N}, 108.5^{\circ} \mathrm{E}\right)$. Nanning has a humid subtropical monsoon climate with an average temperature of $21.7^{\circ} \mathrm{C}$ and abundant rainfall (Deng et al. 2018). The average annual rainfall is $1298 \mathrm{~mm}$, and Nanning has a humid summer and a slightly dry winter with distinctive dry and wet seasons (which result from the impact of the Asian monsoon).

\subsubsection{Sample Collection}

Aerosol samples are collected with a PM-800 large-flow aerosol sampler with a mounted HB1 polypropylene fiber filter membrane and an electric tablet press (Fig. 1). The collection efficiency of the HB1 filter membrane for $0.5 \mu \mathrm{m}$ aerosol particles is approximately $99 \%$. The operational flow of the sampler is set to $600 \mathrm{~m}^{3} / \mathrm{h}$ to ensure that the standardcondition volume of sampling is not smaller than $10,000 \mathrm{~m}^{3}$. After sampling, the volume of air and the start and end times are recorded. The sampling frequency is one sample over approximately $24 \mathrm{~h}$ every month from October 2014 to December 2017. The total number of samples is 39. Each aerosol sample is compressed into a cylinder with a diameter of $70 \mathrm{~mm}$ and a length of $10 \mathrm{~mm}$ (Bourcier et al. 2011; Zhang et al. 2015).

\subsubsection{Sample Analysis}

After encapsulation, the radioactivity was measured with a high-purity germanium gamma (HPGe- $\gamma$ ) spectrometer system containing a model BE3830 detector (CANBERRA) with a crystal size of $\Phi 80 \mathrm{~mm} \times 30 \mathrm{~mm}$. The counting error for radioactivity measurements was approximately $10 \%$ at the 1 sigma level (Lee et al. 2004). The linear energy scale of the analyzer was calibrated with photon peaks from a Co-60 source $(1332 \mathrm{keV})$ with the full width at half maximum (FWHM) of energy no higher than $1.80 \mathrm{keV}$ and with a $50.9 \%$ relative efficiency. The measurement time was longer than $86,400 \mathrm{~s}$, and the minimum detection limits for ${ }^{7} \mathrm{Be}$, ${ }^{210} \mathrm{~Pb}$, and ${ }^{210} \mathrm{Po}$ were $0.017-0.022 \mathrm{mBq} / \mathrm{m}^{3}, 0.01-0.03$ $\mathrm{mBq} / \mathrm{m}^{3}$ and $0.001-0.005 \mathrm{mBq} / \mathrm{m}^{3}$, respectively. The uncertainties of ${ }^{210} \mathrm{~Pb}$ and ${ }^{7} \mathrm{Be}$ activities were controlled to below $5 \%$, and the uncertainties of ${ }^{210}$ Po were approximately $13 \%$.

In this paper, the ${ }^{7} \mathrm{Be}$ and ${ }^{210} \mathrm{~Pb}$ activities were determined with $\gamma$ rays of $477.6 \mathrm{keV}(\mathrm{P} \gamma=10.43 \%)$ and $46.5 \mathrm{keV}(\mathrm{P} \gamma=$ $4.05 \%)$, respectively. The detection efficiency was obtained with laboratory source calibration software (LabSOCS). LabSOCS was considered reliable for gamma ray detector efficiency calibrations, and the deviation of detection efficiency calculated by this method was less than $10 \%$ (Bronson 2003; Li and Geng, 2010; Done et al. 2016). The $\gamma$ energy spectrum data were analyzed with Genie-2000 spectrum analysis software to obtain the activities and uncertainties of ${ }^{210} \mathrm{~Pb}$ and ${ }^{7} \mathrm{Be}$ in the aerosol samples $\left(\mathrm{mBq} / \mathrm{m}^{3}\right)$ (Rastogi and Sarin 2008; Baskaran and Shaw 2001; Leppänen et al. 2010; Dueñas et al. 2011; Du et al. 2020).

After gamma spectrometry analysis, each sample was spiked with ${ }^{209}$ Po as a tracer, and the polonium in the sample was then dissolved with concentrated nitric acid. The residue was dissolved/leached with hydrochloric acid, and ascorbic acid was added thereafter. In the hydrochloric acid system, polonium was self-plated onto a silver disc and determined with an alpha spectrometry (Canberra, 7200-4 PIPS) instrument connected to an Alpha Analyst to calculate the activity of ${ }^{210}$ Po (Carvalho 1995; Huh and Su 1999; Baskaran and Shaw 2001; Daish et al. 2005; Matthews et al. 2007).

\subsection{The HYSPLIT Model}

In this work, we apply the National Oceanic and Atmospheric Administration (NOAA) HYSPLIT model (Stein et al. 2016)
Fig. 1 a The aerosol collector is installed in the integrated automatic monitoring station, and the sampling port is

approximately $2 \mathrm{~m}$ from ground level; $\mathbf{b}$ the inside of the aerosol collector where the filter membrane is placed; $\mathbf{c}$ the filter membrane, where the black areas are aerosols

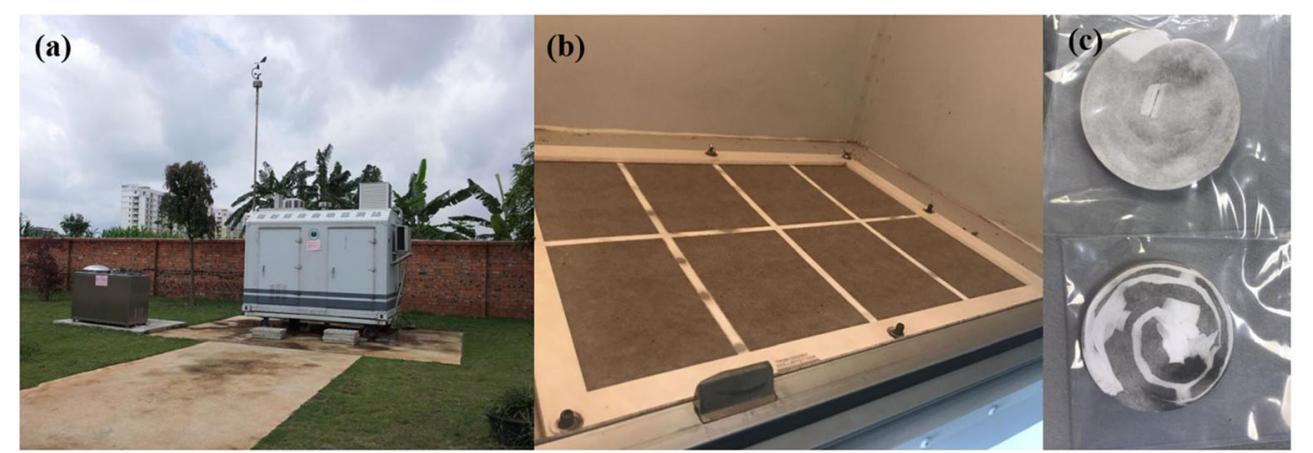


to produce back trajectories in the filtering sampling periods with a duration of $168 \mathrm{~h}$ (7 days). Back trajectories are calculated every six hours over a specific sampling period. The source site is located in Nanning (latitude: $22.8^{\circ} \mathrm{N}$; longitude: $108.5^{\circ} \mathrm{E}$ ), and the height is $100 \mathrm{~m}$ above ground level because the air below $100 \mathrm{~m}$ can be regarded as a uniform mixing layer. The vertical motion calculation method relies on a vertical velocity model, for which we use the meteorology over the sampling period from the National Centers for Environmental Prediction (NCEP) GDAS0p5 (Global Data Assimilation System 0.5 degrees longitude-latitude). Since the number of samples is 39 and the duration of each sampling period is longer than $20 \mathrm{~h}$, there are a total of 144 back trajectories.

\subsection{Linear Regression Search}

For a surface-observed variable $X$, we can define $X=X(\varphi, \lambda, h$, $H, P, A, C)$. Here, $\varphi, \lambda, h$ and $H$ are determined from the HYSPLIT back trajectories, $\varphi$ indicates the maximum and minimum latitudes, $\lambda$ gives the maximum and minimum longitudes, $h$ represents the maximum and minimum altitudes, $H$ is the mixing depth of the planetary boundary layer, and $P$ is the 24$\mathrm{h}$ precipitation rate obtained from the United Kingdom Meteorological Office (UKMO) Hadley Centre. The data analyzed in this work are HadISD version 3.1.0.201911p (Dunn et al. 2012, 2014, 2016). $A$ is the AOI, which is the daily mean data obtained from the National Centers for Environmental Prediction (NCEP)/National Center for Atmospheric Research (NCAR) reanalysis (Zhou et al. 2001), and $C$ indicates the ground-level cosmic ray observations obtained from the cosmic ray station of the Sodankyla Geophysical Observatory, University of Oulu, Finland (Mishev et al. 2014).

The daily AO index is obtained from the National Oceanic and Atmospheric Administration (NOAA) Climate Prediction Center (ftp://ftp.cpc.ncep.noaa.gov/cwlinks/norm.daily.ao. index.b500101.current.ascii). The daily AO index is calculated via methods similar to Thompson and Wallace (2000) and Thompson et al. (2000). The daily AO index is determined by projecting the daily $1000 \mathrm{hPa}$ height anomalies at latitudes north of $20^{\circ} \mathrm{N}$ onto the leading empirical orthogonal function (EOF) (https://www.cpc.ncep.noaa.gov/products/ precip/CWlink/daily ao index/ao.shtml). The monthly mean $1000 \mathrm{hPa}$ height anomalies north of $20^{\circ} \mathrm{N}$ are used to construct the EOF. The daily AO index is normalized by the standard deviation of the monthly index (based on the 1979-2000 period). NCEP/NCAR reanalysis data at 2.5 degree longitudelatitude resolution are used in the construction of the monthly EOF (https://www.cpc.ncep.noaa.gov/products/precip/ CWlink/daily ao index/history/method.shtml). The positive $\mathrm{AO}$ index corresponds to negative height anomalies over the polar region, and vice versa (Thompson et al. 2000).
To rank the effects of the above parameters on the surfaceobserved $X$, we apply a linear regression model to compute the statistical correlations between both the observed $X$ and variables and among the variables (Wang and Chau 2013). The correlations between two variables are measured by the calculated correlation coefficient $R$. The statistical significance of a correlation is tested by computing Student's $t$ test probability P (Press et al. 1992).

\subsection{The US EML Global Air Sampling Data}

The US EML has a network of air sampling sites that measure ${ }^{7} \mathrm{Be},{ }^{210} \mathrm{~Pb}$, and other nuclides on a global scale (Larsen et al. 1995). The global coverage of EML surface sites is excellent for comparing and testing the results obtained from the analysis of local measurements performed in Nanning. It is important to test whether the results obtained from Nanning are specific only to Nanning or whether they are general features on a global scale. In this context, the EML data serve as a testbed for verifying the results obtained from the Nanning data.

\section{Results}

\subsection{Time-Series Measurements}

Time-series measurements of ${ }^{7} \mathrm{Be},{ }^{210} \mathrm{~Pb}$, and ${ }^{210} \mathrm{Po}$ over 39 months from 2014 to 2017 are shown in Fig. 2(a). The average specific activity of ${ }^{7} \mathrm{Be}$ is $4.21 \mathrm{mBq} / \mathrm{m}^{3}$ and is in the range of $0.39-12.70 \mathrm{mBq} / \mathrm{m}^{3}$. The average specific activity of ${ }^{210} \mathrm{~Pb}$ is $1.51 \mathrm{mBq} / \mathrm{m}^{3}$ and is in the range of $0.23-3.92 \mathrm{mBq} /$ $\mathrm{m}^{3}$. The average specific activity of ${ }^{210} \mathrm{Po}$ is $0.61 \mathrm{mBq} / \mathrm{m}^{3}$ and is in the range of $0.17-1.68 \mathrm{mBq} / \mathrm{m}^{3}$. The activity level of ${ }^{7} \mathrm{Be}$ is higher than the global average level of $2.45 \mathrm{mBq} / \mathrm{m} 3$ based on long-term observations of more than 70 stations around the world (Koch et al. 1996). The activity of ${ }^{7} \mathrm{Be}$ is comparable to that determined at other observation stations (EML data, as shown in Fig. 5). The activities of ${ }^{210} \mathrm{~Pb}$ and ${ }^{210} \mathrm{Po}$ in the ambient aerosols mostly exceed the simulated values at 0.5 and $0.05 \mathrm{mBq} / \mathrm{m}^{3}$, respectively (UNSCEAR 2000). However, the activity levels of ${ }^{210} \mathrm{~Pb}$ and ${ }^{210} \mathrm{Po}$ at Nanning are comparable to those over other cities in China (Pan et al. 2017). The three nuclides exhibit a seasonal variation pattern: higher activity in winter and lower activity in summer. The overall concentration of ${ }^{7} \mathrm{Be}$ is higher than that of ${ }^{210} \mathrm{~Pb}$ and ${ }^{210} \mathrm{Po}$, and its fluctuation is also more notable. Rainfall is the main process of aerosol removal from the atmosphere. Rainfall is abundant in the summertime in Nanning, which decreases ${ }^{210} \mathrm{~Pb}$ and ${ }^{210} \mathrm{Po}$, similar to ${ }^{7} \mathrm{Be}$. Although the production rate of ${ }^{7} \mathrm{Be}$ at any given latitude in the atmosphere does not change with the season, the seasonal intrusion of lower stratospheric air and washout of atmospheric aerosols carrying ${ }^{7} \mathrm{Be}$ leads to the enrichment of ${ }^{7} \mathrm{Be}$ during late winter and early spring, 


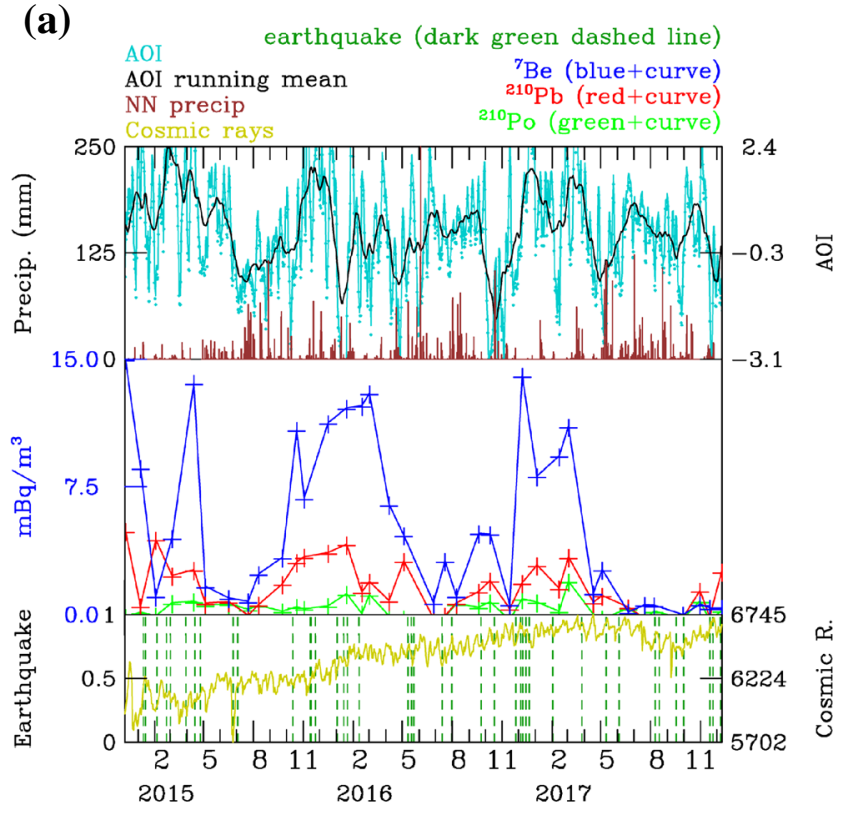

(b)

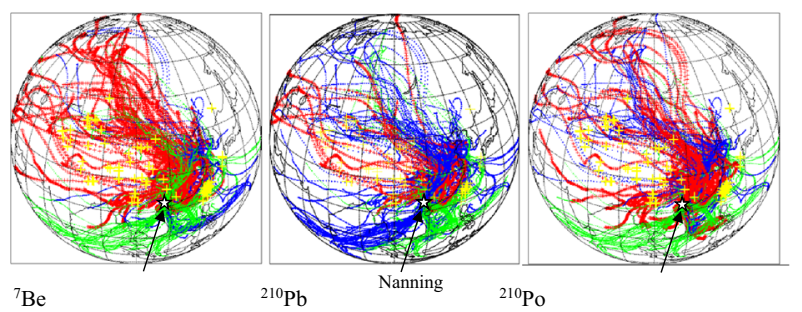

Fig. 2 a Time series of the activity of the three nuclides $\left({ }^{7} \mathrm{Be},{ }^{210} \mathrm{~Pb}\right.$, and ${ }^{210} \mathrm{Po}$ ), the AOI, earthquake events, cosmic rays, and precipitation in Nanning from $9 / 10 / 2014$ to $10 / 12 / 2017$; b trajectory map for (i) ${ }^{7} \mathrm{Be}$ : green $\left(0-3.0 \mathrm{mBq} / \mathrm{m}^{3}\right)$, blue $\left(3.0-6.0 \mathrm{mBq} / \mathrm{m}^{3}\right)$, and red $(6.0-9.0 \mathrm{mBq} /$ $\left.\mathrm{m}^{3}\right)$; (ii) ${ }^{210} \mathrm{~Pb}$ : green $\left(0-1.0 \mathrm{mBq} / \mathrm{m}^{3}\right)$, blue $\left(1.0-2.0 \mathrm{mBq} / \mathrm{m}^{3}\right)$, and red $\left(2.0-3.0 \mathrm{mBq} / \mathrm{m}^{3}\right)$; (iii) ${ }^{210} \mathrm{Po}$ : green $\left(0-0.5 \mathrm{mBq} / \mathrm{m}^{3}\right)$, blue $(0.5-1.0 \mathrm{mBq} /$ $\left.\mathrm{m}^{3}\right)$, and red $\left(1.0-1.5 \mathrm{mBq} / \mathrm{m}^{3}\right)$. The Nanning monitoring site is highlighted by bold white stars and arrows and is indicated in the central figure

which does not occur in summer (Marenco and Fontan 1974; Feely et al. 1989; Du et al. 2020).

${ }^{7} \mathrm{Be}$ is a cosmogenic radionuclide that is mainly produced in the stratosphere. Due to cosmic rays, ${ }^{7} \mathrm{Be}$ is continuously produced. Ground-level cosmic ray observations revealed a persistent increasing trend from October 2014 to December 2017. Despite increasing cosmic rays, the activity of ${ }^{7} \mathrm{Be}$ in the near-surface air did not persistently increase. Hence, the variations in ground-level ${ }^{7} \mathrm{Be}$ concentrations are more associated with $\mathrm{AO}$ patterns than with changes in the incoming cosmic rays. The back trajectory analysis (Fig. 2(b)) clearly shows that almost all of the higher concentrations of ${ }^{7} \mathrm{Be}$ originate from middle and high latitudes. Some of the trajectories start in polar regions. These back trajectories indicate that ${ }^{7} \mathrm{Be}$ observed near the ground in Nanning was affected by air from middle and high northern latitudes
The activities of ${ }^{210} \mathrm{~Pb}$ and its progeny ${ }^{210} \mathrm{Po}$ exhibit seasonal variation, with low concentrations in summer and high concentrations in winter. The back trajectory maps of ${ }^{210} \mathrm{~Pb}$ and ${ }^{210} \mathrm{Po}$ are shown in Fig. 2(b). The back trajectories of the higher concentrations are overwhelmingly distributed over the land area. Oceanic air masses from the South China Sea play a dominant role in affecting the weather in Nanning in summer with negligible ${ }^{222} \mathrm{Rn}$ activity, while the back trajectories of the land air masses in winter indicate higher ${ }^{222} \mathrm{Rn}$ activity. Therefore, the activity of the ${ }^{222} \mathrm{Rn},{ }^{210} \mathrm{~Pb}$ and ${ }^{210} \mathrm{Po}$ progenies exhibits the same seasonal distribution in aerosols (Carvalho 1995; Dueñas et al. 2011).

\subsection{Correlation Analysis}

Figure 3(a) shows that the correlation between ${ }^{7} \mathrm{Be}$ and the AOI is the most significant, with an $\mathrm{R}=0.26$, and the $P$ value is 0.0268 , followed by ${ }^{210} \mathrm{~Pb}$, with an $\mathrm{R}=0.20$ and a $\mathrm{P}$ value of 0.0826 . The correlation between ${ }^{210} \mathrm{Po}$ and the $\mathrm{AO}$ is an $\mathrm{R}$ value of 0.29 and a $P$ value of 0.0138 . More noteworthy discussions are presented below. As a tracer of the STE, the correlation of ${ }^{7} \mathrm{Be}$ versus ${ }^{210} \mathrm{~Pb}$ is significant, with $\mathrm{R}=0.62$ and a $\mathrm{P}$ value $<0.01$ (Fig. 3(c)). Precipitation is negatively correlated with the ${ }^{7} \mathrm{Be}$ concentration, with $\mathrm{R}=0.30$ and a $\mathrm{P}$ value $=0.11$ (Fig. 3(b)). Note that Fig. 3(a) also shows that low levels of ${ }^{7} \mathrm{Be}$ (less than $1 \mathrm{mBq} / \mathrm{m}^{2}$ ) are also associated with a high AOI, indicating the involvement of multiple processes in the scatter diagram.

Figure 3(b) shows negative correlations between ${ }^{7} \mathrm{Be}$, ${ }^{210} \mathrm{~Pb}$ and precipitation. The negative correlation between ${ }^{210} \mathrm{~Pb}$ and precipitation is characterized by $\mathrm{R}=0.35$ and a $P$ value of 0.06 , while ${ }^{210} \mathrm{Po}$ shows no clear correlation with precipitation. An earthquake is the source event for ${ }^{210} \mathrm{~Pb}$ and ${ }^{210} \mathrm{Po}$. Due to crustal rupture, a high concentration of ${ }^{222} \mathrm{Rn}$ can diffuse from crustal soil to the atmosphere. Therefore, seismic events may be able to explain the shortterm and sudden high-activity events of ${ }^{210} \mathrm{~Pb}$ and ${ }^{210} \mathrm{Po}$ as long half-life progenies of ${ }^{222} \mathrm{Rn}$. However, seismic signals are relatively complex and are not explained in this work.

To clarify the effect of the $\mathrm{AO}$ on ${ }^{7} \mathrm{Be}$, we perform a series of sensitivity tests with various durations (from 2 to 7 days) of the back trajectories. The test results reveal that the 6-7 day back trajectories result in the most significant correlation $(\mathrm{R}=$ 0.46 and $P$ value $<0.01$ ) between ${ }^{7} \mathrm{Be}$ and height. Hence, correlation analysis is performed on these four variables (AOI, ${ }^{7} \mathrm{Be}$, latitude, and altitude) by considering three AOI cases (all, positive phase, and negative phase (see Fig. 4)). For data reliability, a comparison between the EML and Nanning observation data is conducted via scatter plot analysis of ${ }^{7} \mathrm{Be}$ versus AOI and of ${ }^{210} \mathrm{~Pb}$ versus ${ }^{7} \mathrm{Be}$.

Figure 4(a) shows that 63\% (90/142) of the back trajectories in the case of $\mathrm{AOI}>0$ originate in the $\mathrm{NH}$ polar region and mid-latitude regions. The back trajectories for $\mathrm{AOI}<0(37 \%)$ 
(a)

Data Period 2014/10-2017/12; Nanning

Data Period 2014/10-2017/12; Nanning

Data Period 2014/10-2017/12; Nanning $\mathrm{y}=3.61+1.04 \mathrm{x} ; \mathrm{N}=74 ; \mathrm{R}=0.26 ; \mathrm{P}-$ value $=0.0268 \mathrm{y}=1.39+0.24 \mathrm{x} ; \mathrm{N}=74 ; \mathrm{R}=0.20 ; \mathrm{P}-$ value $=0.0826 \mathrm{y}=0.58+0.12 \mathrm{x} ; \mathrm{N}=74 ; \mathrm{R}=0.29 ; \mathrm{P}-$ value $=0.0138$
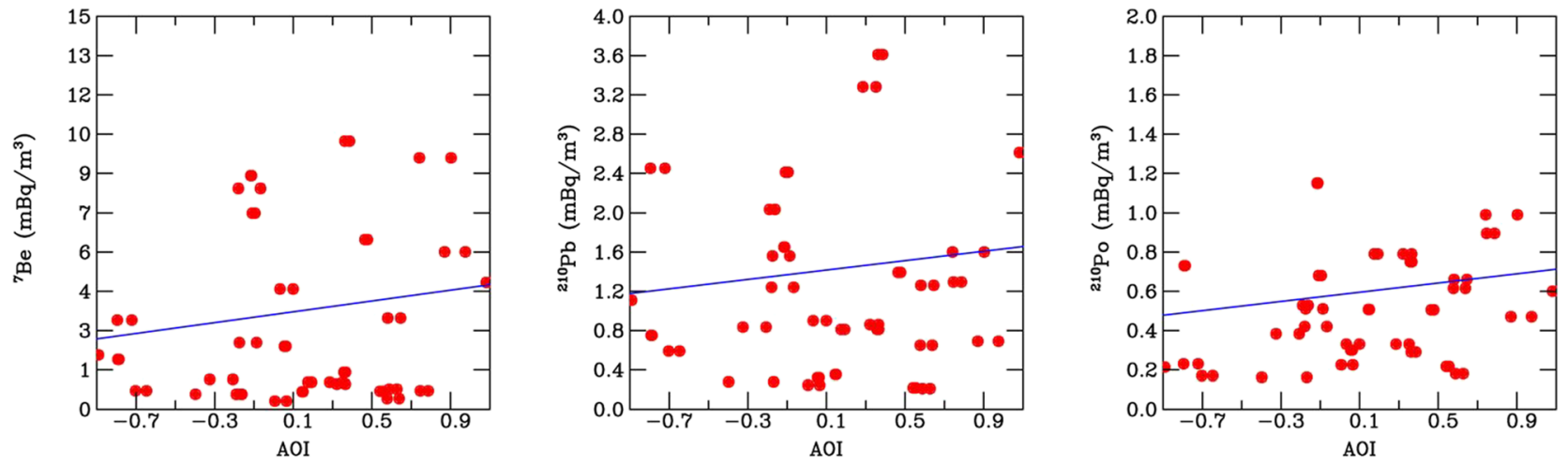

(b)

Data Period 2014/10-2017/12; Nanning

Data Period 2014/10-2017/12; Nanning

Data Period 2014/10-2017/12; Nanning $\mathrm{y}=2.93+-0.06 \mathrm{x} ; \mathrm{N}=29 ; \mathrm{R}=0.30 ; \mathrm{P}-$ value $=0.1132 \mathrm{y}=1.51+-0.03 \mathrm{x} ; \mathrm{N}=29 ; \mathrm{R}=0.35 ; \mathrm{P}-$ value $=0.0603$
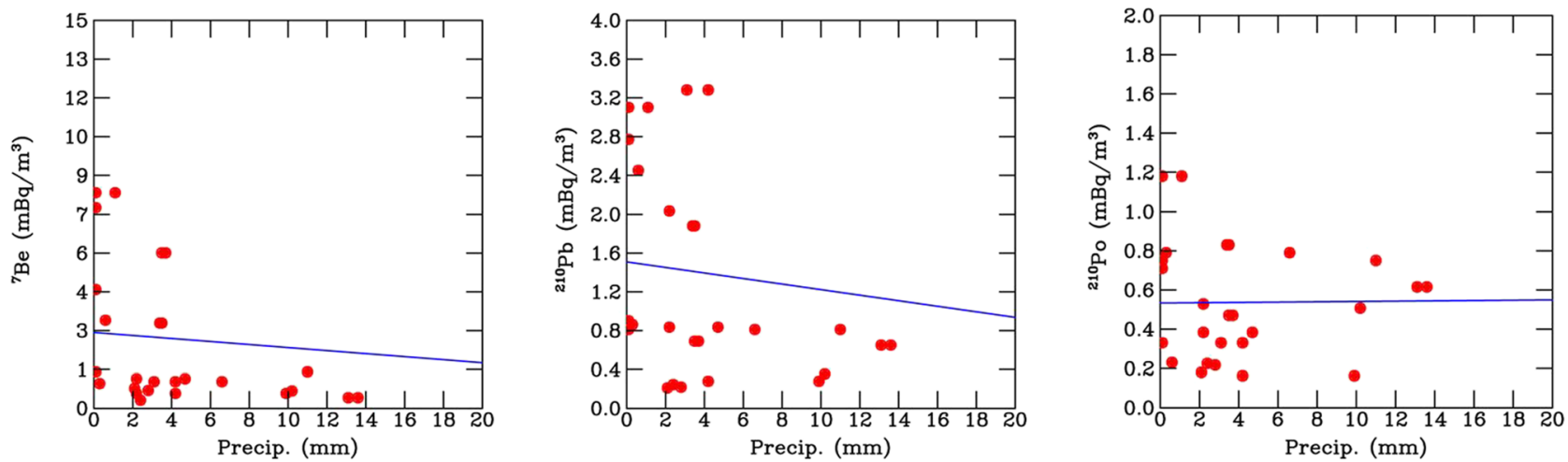

(c)

Data Period 2014/10-2017/12; Nanning Data Period 2014/10-2017/12; Nanning $\mathrm{y}=0.74+0.18 \mathrm{x} ; \mathrm{N}=74 ; \mathrm{R}=0.62 ; \mathrm{P}$-value $<0.01 \mathrm{y}=0.43+0.05 \mathrm{x} ; \mathrm{N}=74 ; \mathrm{R}=0.46 ; \mathrm{P}$-value $<0.01$

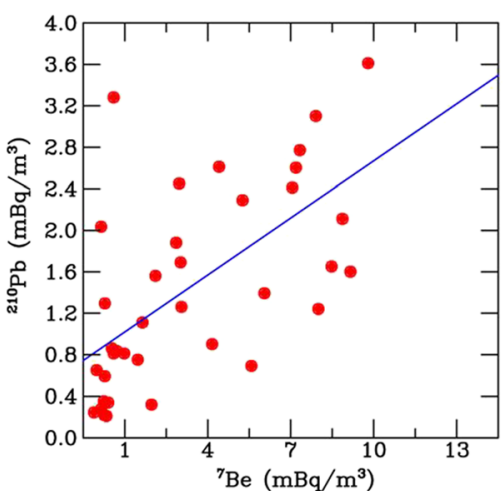

Fig. 3 Scatter plots of the observed variables versus the AOI. a The three radionuclides $\left({ }^{7} \mathrm{Be}\right.$ (left panel), ${ }^{210} \mathrm{~Pb}$ (central panel), and ${ }^{210} \mathrm{Po}$ (right panel)) versus the AOI. b The three radionuclides ( ${ }^{7} \mathrm{Be}$ (left panel),

are confined to latitudes south of $50^{\circ} \mathrm{N}$. Both ${ }^{7} \mathrm{Be}$ and the AOI exhibit a significant correlation with the maximum altitudes and latitudes of the HYSPLIT back trajectories (Fig. 4(b, c, d, e)). Especially in the case of $\mathrm{AO}>0$, all the correlations are more notable. Regarding the AOI versus latitude, the $\mathrm{R}=0.28$ in the case of all AOI data ( $P$ value $<0.01$; Fig. 4(b), left

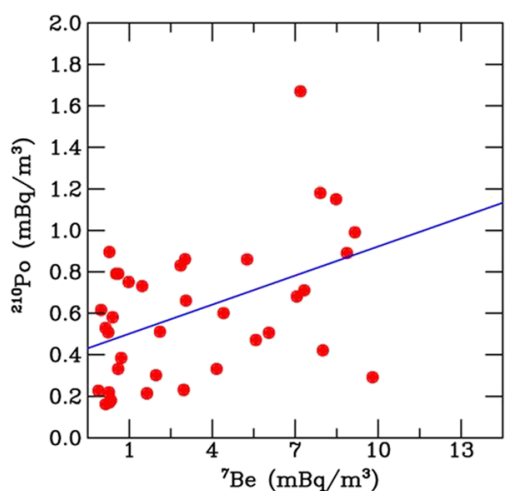

${ }^{210} \mathrm{~Pb}$ (central panel), and ${ }^{210} \mathrm{Po}$ (right panel)) versus precipitation. c Correlations between ${ }^{210} \mathrm{~Pb}$ and ${ }^{7} \mathrm{Be}$ (left panel) and between ${ }^{210} \mathrm{Po}$ and ${ }^{7} \mathrm{Be}$ (right panel)

panel). The correlation coefficient $\mathrm{R}$ increased to $\mathrm{R}=0.48$ in the case of AOI $>0$ (P value $<0.01$; Fig. 4(b), middle panel). In terms of the $\mathrm{AOI}$ versus altitude, the $\mathrm{R}=0.10$ in the case of all AOI data (Fig. 4(c), left panel). The correlation coefficient $R$ increased to $R=0.32$ in the case of $A O>0$ ( $P$ value $<0.01$; Fig. 4(c), middle panel). 
(a)

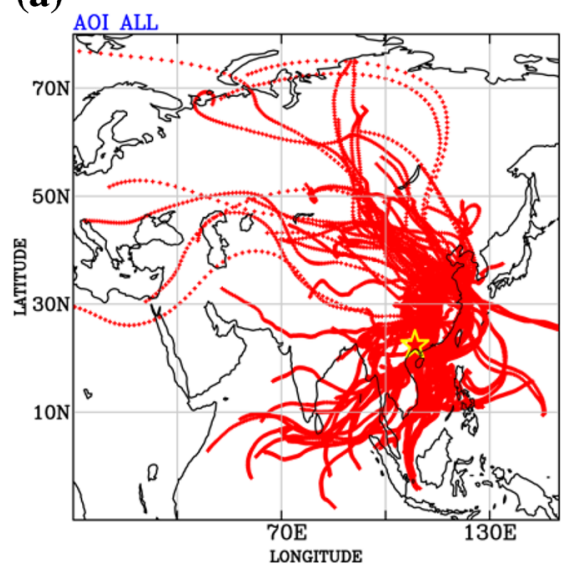

(b)

\section{AOI Vs Latitude}

Time 2014/10-2017/12; Nanning AOI ALL;6-d btj $y=26.95+7.49 x ; N=142 ; R=0.28 ; P-$ value $<0.01$

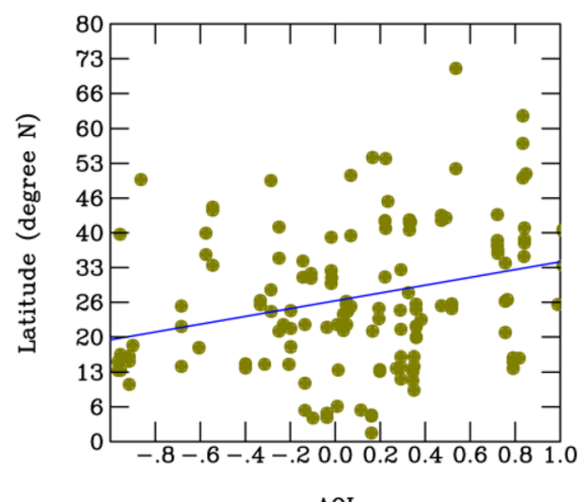

AOI

(c)

AOI Vs Altitude

Time 2014/10-2017/12; Nanning AOI ALL;6-d btj $y=2.33+0.69 x ; N=142 ; R=0.18 ; P-$ value $=0.0287$

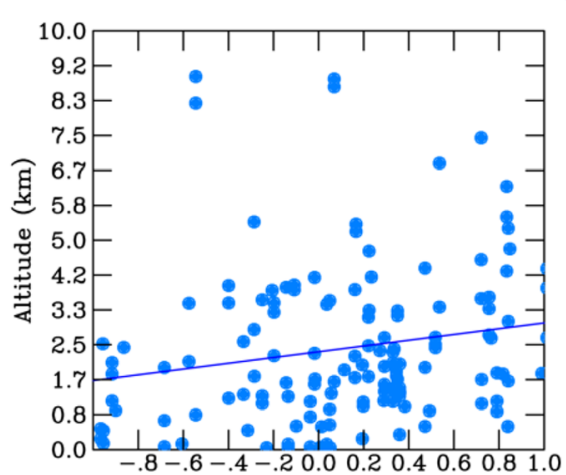

AOI

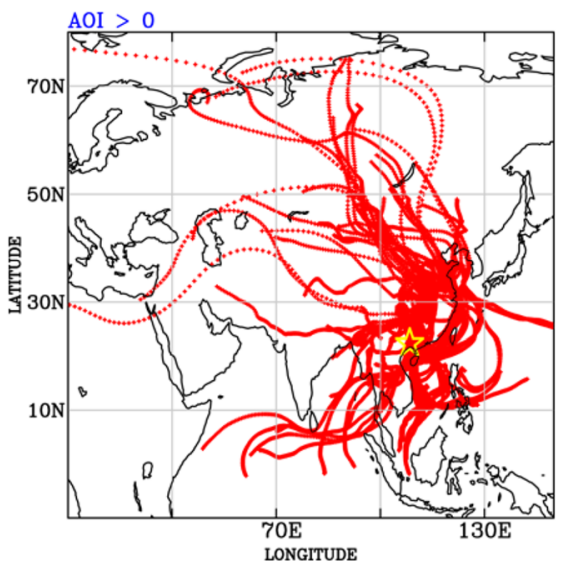

AOI Vs Latitude

Time 2014/10-2017/12; Nanning AOI > 0;6-d btj $y=22.58+16.85 x ; N=90 ; R=0.35 ; P-$ value $<0.01$

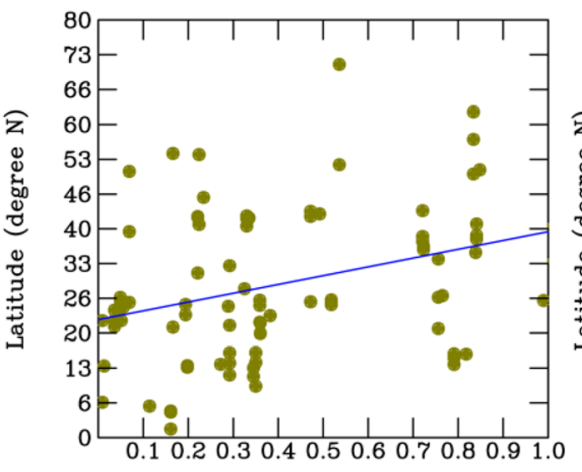

AOI

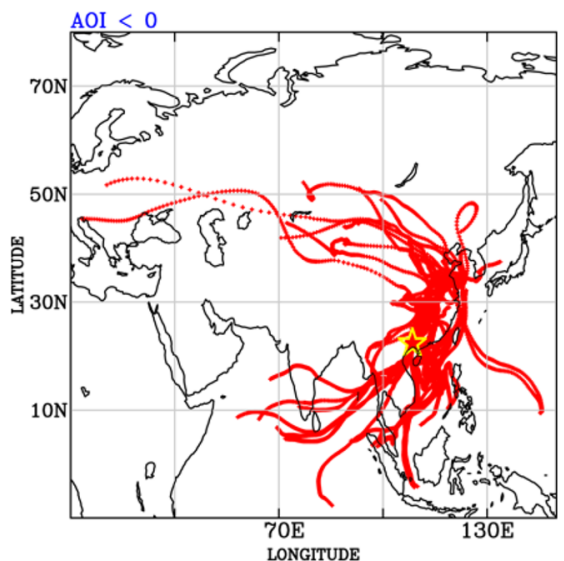

AOI Vs Latitude

Time 2014/10-2017/12; Nanning AOI $<0 ; 6-d$ btj $\mathrm{y}=25.46+1.71 \mathrm{x} ; \mathrm{N}=52 ; \mathrm{R}=0.05 ; \mathrm{P}$-value $=0.7342$

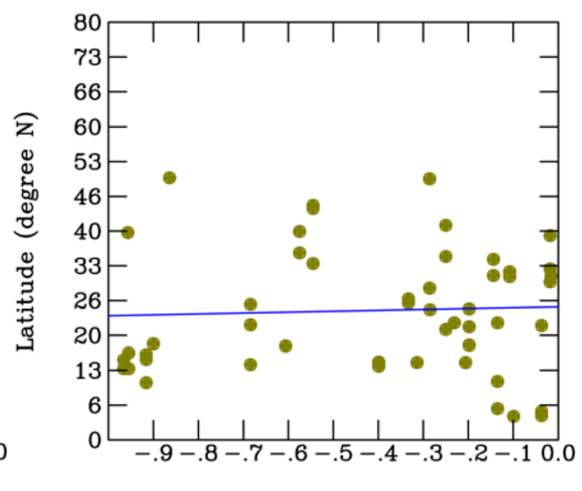

AOI
AOI Vs Altitude

Time 2014/10-2017/12; Nanning AOI > 0;6-d btj $\mathrm{y}=1.86+1.64 \mathrm{x} ; \mathrm{N}=90 ; \mathrm{R}=0.26 ; \mathrm{P}$-value $=0.0144$

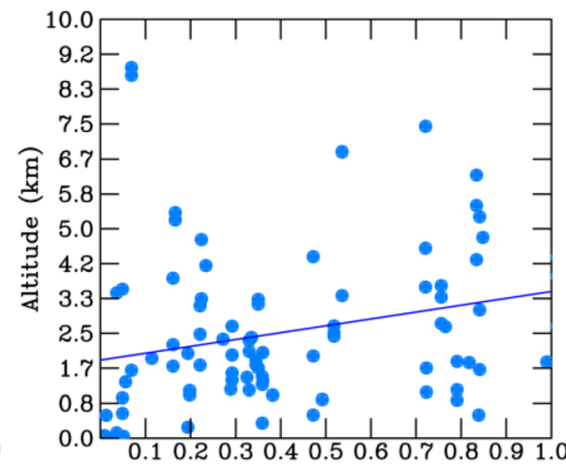

AOI Vs Altitude

Time 2014/10-2017/12; Nanning AOI < 0;6-d btj $y=2.38+0.47 x ; N=52 ; R=0.08 ; P-$ value $=0.5667$

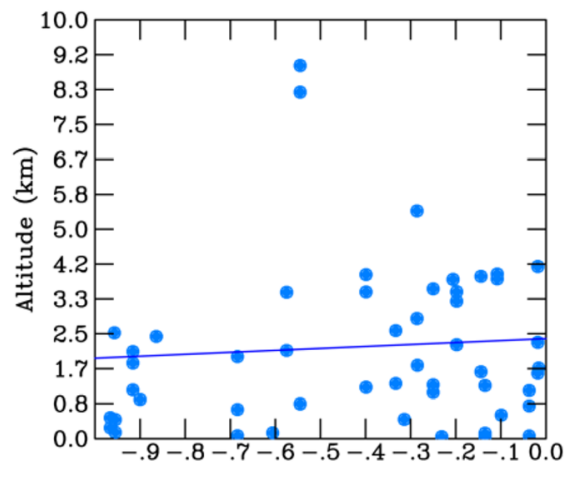

AOI
Fig. 4 Scatter plots of ${ }^{7} \mathrm{Be}$ measurements versus the highest altitudes and latitudes of the air mass back trajectories from HYSPLIT. a Spatial distribution of the back trajectories: all AOIs (left panel), positive AOIs (middle panel), and negative AOIs (right panel). b All AOIs (left panel), positive AOIs (central panel), and negative AOIs (right panel) versus

AOI

latitude. c All AOIs (left panel), positive AOIs (central panel), and negative AOIs (right panel) versus altitude. $\mathbf{d}$ Altitude versus ${ }^{7} \mathrm{Be}$ for all AOIs (left panel), positive AOIs (central panel), and negative AOIs (right panel). e Latitude versus ${ }^{7} \mathrm{Be}$ (left panel) and altitude versus latitude (right panel) for positive AOIs

The correlation between altitude and ${ }^{7} \mathrm{Be}$ is significant, with $\mathrm{R}=0.40$ in the case of all AOI data (Fig. 4(d), left panel). The correlation coefficient is $\mathrm{R}=0.37$ in the case of $\mathrm{AOI}>0$

(P value $<0.01$; Fig. 4(d), middle panel). These results prove that the sources of the elevated ${ }^{7} \mathrm{Be}$ are located at high altitudes. The correlations between latitude and ${ }^{7} \mathrm{Be}(\mathrm{R}=0.56$ in 
(d)

Altitude Vs ${ }^{7} \mathrm{Be}$

Time 2014/10-2017/12; Nanning AOI ALL;6-d btj

$\mathrm{y}=2.08+0.75 \mathrm{x} ; \mathrm{N}=144 ; \mathrm{R}=0.43 ; \mathrm{P}-$ value $<0.01$

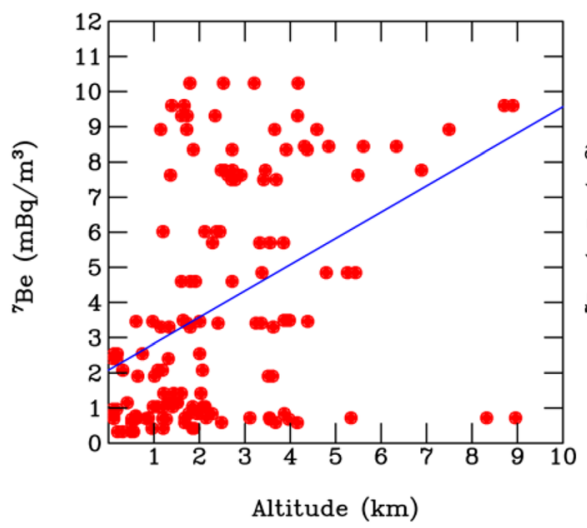

(e)
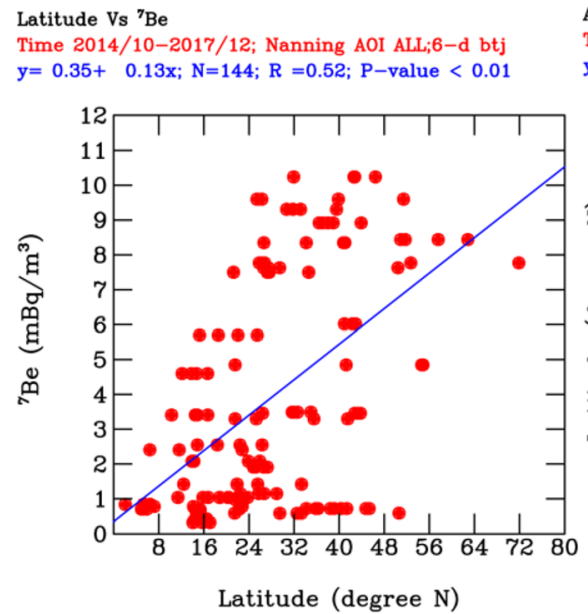

Fig. 4 (continued).

the case of AOI $>0$, with a P value $<0.01$; Fig. 4(e), left panel) prove that elevated ${ }^{7} \mathrm{Be}$ is associated with higher latitudes in the NH. The latitude versus altitude correlations $(\mathrm{R}=0.61$, with a $P$ value $<0.01$; Fig. $4(\mathrm{e})$, right panel) demonstrate that the high-latitude air masses originated from the $\mathrm{NH}$ high latitudes.

The polar stratosphere exhibits the highest ${ }^{7}$ Be production rate, while the tropical lower troposphere experiences the lowest ${ }^{7} \mathrm{Be}$ production rate (Feely et al. 1989). The variations in the AO exhibit chains of coupled flow pattern changes from the polar stratosphere downward toward the lower-latitude troposphere. With the AO as a key mechanism, air parcels move from higher latitudes and altitudes (the polar stratosphere that is rich in ${ }^{7} \mathrm{Be}$ ) to lower latitudes and altitudes (the tropical troposphere) when the AO is positive, and East Asia experiences a more notable STE. Therefore, it is easy to understand that with the higher altitudes and latitudes of the HYSPLIT trajectories, it is more likely for the air enriched in ${ }^{7} \mathrm{Be}$ to be transported from the stratosphere to troposphere, as
Altitude Vs ${ }^{7} \mathrm{Be}$

Time 2014/10-2017/12; Nanning AOI $<0 ; 6-\mathrm{d}$ btj $\mathrm{y}=2.39+0.25 \mathrm{x} ; \mathrm{N}=54 ; \mathrm{R}=0.17 ; \mathrm{P}-$ value $=0.2229$

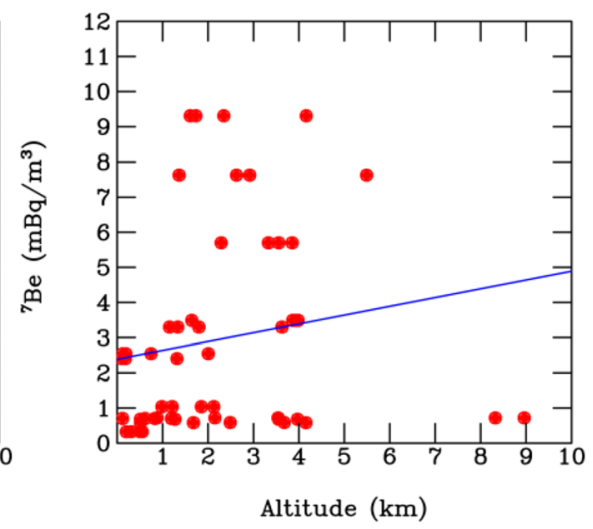

Altitude Vs Latitude

Time 2014/10-2017/12; Nanning AOI > 0;6-d btj $\mathrm{y}=18.58+4.30 \mathrm{x} ; \mathrm{N}=90 ; \mathrm{R}=0.57 ; \mathrm{P}$-value $<0.01$

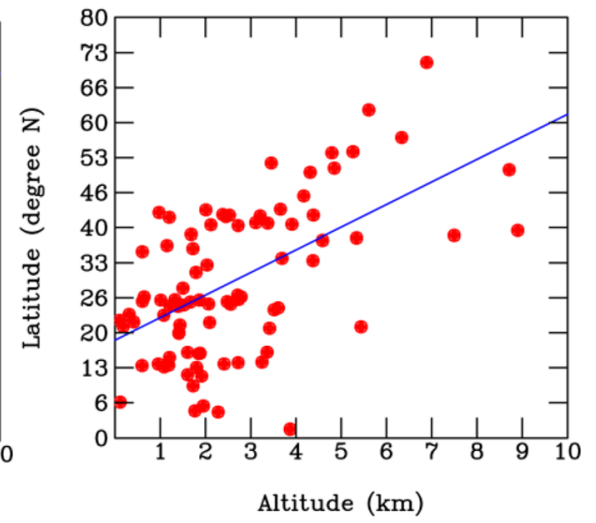

well as from the high to low latitudes. These processes explain why the AOI exhibits good correlations with ${ }^{7} \mathrm{Be}$. These four aspects $\left({ }^{7} \mathrm{Be}, \mathrm{AOI}\right.$, latitude, and altitude) are notably correlated through analysis of the back trajectories.

In summary, Fig. 4 demonstrates that elevated ${ }^{7} \mathrm{Be}$ is associated with air coming from high latitudes (polar regions) and high altitudes (lower stratosphere). In the case of AOI $>0$, strong and positive regression correlations exist between latitude and altitude versus ${ }^{7} \mathrm{Be}$ and between altitude versus latitude. In the case of $\mathrm{AOI}<0$, a weak positive regression is observed. All correlation coefficients are statistically significant $(P$ value $<0.01$ for positive phases of the AO). These results indicate that the air masses enriched in ${ }^{7} \mathrm{Be}$ originate from polar regions and the lower stratosphere. The disturbance and variability of the polar vortex, exhibited as the $\mathrm{AOI}$, are the main causes of the elevated ${ }^{7} \mathrm{Be}$ observed at the tropical Nanning site.

The back-trajectory computation strongly supports our findings of the dominant role of the $\mathrm{AO}$ in controlling the 
Fig. 5 Scatter plots of EML data versus Nanning data. a At Barrow, ${ }^{7} \mathrm{Be}$ versus ${ }^{210} \mathrm{~Pb}$, and (b) AOI versus ${ }^{7} \mathrm{Be}$. Panels (c) and (d) are the same as (a) and (b) but for Montgomery, Alabama. Red crosses represent Nanning data, and red straight lines are linear regression model results. Blue crosses represent EML data, and blue straight lines are linear regression model results (a)

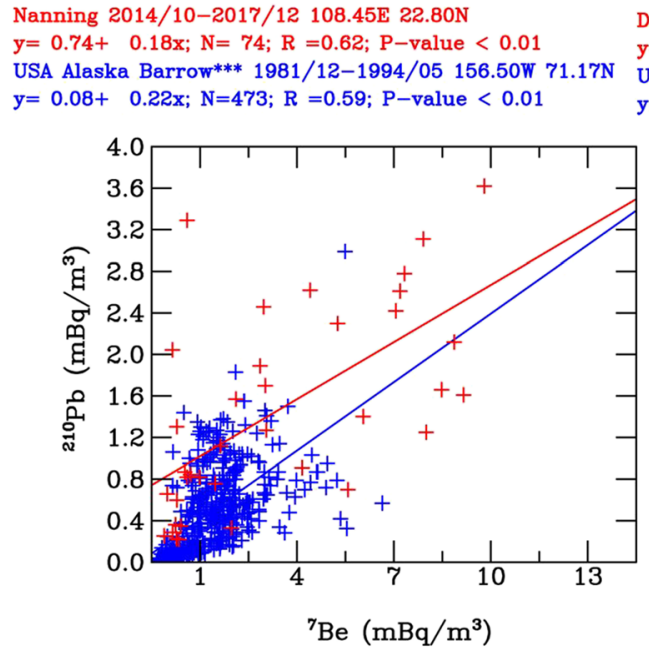

(c)

Nanning $2014 / 10-2017 / 12108.45 \mathrm{E} 22.80 \mathrm{~N}$
$\mathrm{y}=0.74+\quad 0.18 \mathrm{x} ; \mathrm{N}=74 ; \mathrm{R}=0.62 ; \mathrm{P}-$ value $<0.01$
USA Alabama Montgome $1989 / 09-1994 / 0586.32 \mathrm{~W}$ USA Alabama Montgome $1989 / 09-1994 / 05$
$\mathrm{y}=0.38+0.08 \mathrm{x} ; \mathrm{N}=141 ; \mathrm{R}=0.49 ; \mathrm{P}-$ value $<0.01$

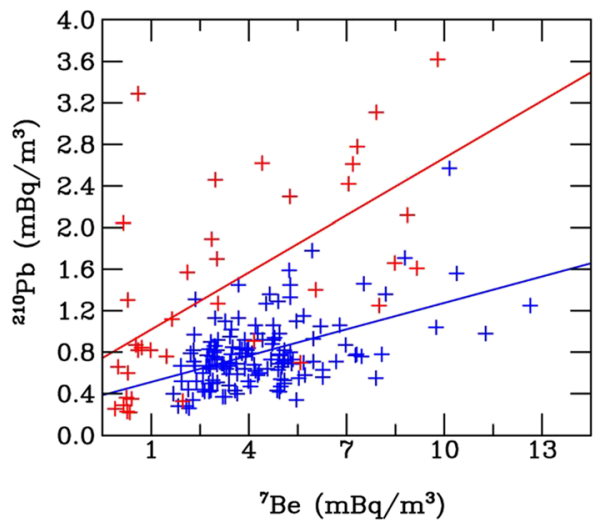

(b)

Data Period 2014/10-2017/12; Nanning $\mathrm{y}=2.34+2.26 \mathrm{x} ; \mathrm{N}=34 ; \mathrm{R}=0.40 ; \mathrm{P}-$ value $=0.0193$ USA Alaska Barrow*** 1981/12-1994/05 156.50W 71.17N $\mathrm{y}=1.60+0.27 \mathrm{x} ; \mathrm{N}=241 ; \mathrm{R}=0.09 ; \mathrm{P}-$ value $=0.1770$

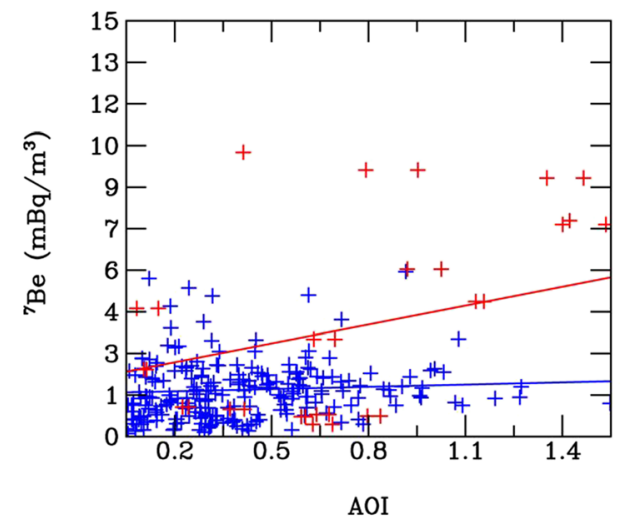

(d)

Data Period 2014/10-2017/12; Nanning $\mathrm{y}=2.34+2.26 \mathrm{x} ; \mathrm{N}=34 ; \mathrm{R}=0.40 ; \mathrm{P}$-value $=0.0193$ NUSA Alabama Montgome 1989/09-1994/05 86.32W 32.38N $\mathrm{y}=4.60+0.69 \mathrm{x} ; \mathrm{N}=86 ; \mathrm{R}=0.13 ; \mathrm{P}-$ value $=0.2198$

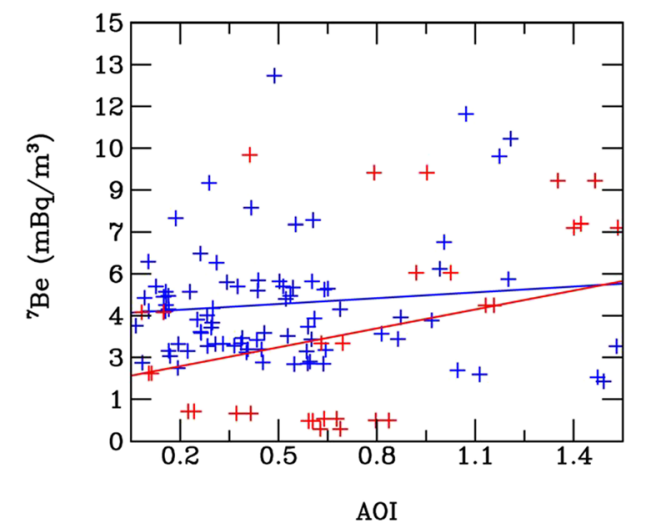

abundance of ${ }^{7} \mathrm{Be}$ (Fig. 3(a)) and the significant correlation between ${ }^{7} \mathrm{Be}$ and ${ }^{210} \mathrm{~Pb}$ (Fig. 3(c)). Moreover, based on the meteorology along the back trajectories, we perform further correlation analyses (Fig. 4) and prove that the air masses enriched in ${ }^{7} \mathrm{Be}$ originate from the polar regions and the lower stratosphere.

\subsection{Comparisons with EML Data}

For data reliability and to test our results, scatter plot analysis of ${ }^{7} \mathrm{Be}$ versus $\mathrm{AOI}$ and ${ }^{210} \mathrm{~Pb}$ versus ${ }^{7} \mathrm{Be}$ was again performed on the EML data, which contains more than 6000 observations on a global scale. Figure 5 shows the sites in the $\mathrm{NH}$ that have similar patterns as Nanning. Figures 6 and 7 show the sites in the Southern Hemisphere $(\mathrm{SH})$ that exhibit both positive correlations between the AOI and ${ }^{7} \mathrm{Be}$ and between ${ }^{7} \mathrm{Be}$ and ${ }^{210} \mathrm{~Pb}$. The correlation analysis results are statistically significant.
In Perth $\left(32^{\circ} \mathrm{S}\right)$, Australia, ${ }^{7} \mathrm{Be}$ is correlated with the AOI with an $\mathrm{R}=0.11$, and ${ }^{210} \mathrm{~Pb}$ is correlated with ${ }^{7} \mathrm{Be}$ with an $\mathrm{R}=$ $0.36(P<0.01)$. In Tasmania $\left(40.73^{\circ} \mathrm{S}\right)$, Australia, the ${ }^{7} \mathrm{Be}$ versus AOI correlation has an $\mathrm{R}$-value of 0.11 , and the ${ }^{210} \mathrm{~Pb}$ versus ${ }^{7} \mathrm{Be}$ correlation has an $\mathrm{R}$-value of $0.21(p<0.01)$. On Reunion Island $\left(21.10^{\circ} \mathrm{S}\right)$, the ${ }^{210} \mathrm{~Pb}$ versus ${ }^{7} \mathrm{Be}$ correlation has an $\mathrm{R}$-value of $0.36(\mathrm{P}<0.01)$. The comparisons show that similar latitudes exhibit similar ranges of ${ }^{7} \mathrm{Be}$ concentrations and correlation coefficients between $210 \mathrm{~Pb}$ and ${ }^{7} \mathrm{Be}(\mathrm{R}=0.31$, $\mathrm{P}<0.01$ ), while the ${ }^{210} \mathrm{~Pb}$ correlation coefficient range is half of that at the Nanning site (due to abundant fossil fuel burning). The patterns from the 5 Australian sites are consistent, which verifies that they are correct.

In the $\mathrm{NH}$, many sites exhibit a very good linear correlation between ${ }^{210} \mathrm{~Pb}$ and ${ }^{7} \mathrm{Be}$ and are geographically associated with large mountain ranges in the $\mathrm{NH}$, such as the Himalayas, Alps, and Rocky Mountains (Fig. 8(a)). The downwind areas of high mountains easily experience vertical air oscillations, thus intensifying the instability of tropospheric air and increasing 
Fig. 6 The same as Fig. 5, but for sites in the SH. Panels (a) and (b) are for Reunion Island. Panels (c) and (d) are for Norfolk, Australia. Panels (e) and (f) are for Perth, Australia (a)

Nanning 2014/10-2017/12 108.45E 22.80N

$\mathrm{y}=0.74+\quad 0.18 \mathrm{x} ; \mathrm{N}=74 ; \mathrm{R}=0.62 ; \mathrm{P}-$ value $<0.01$ France Reunion Islan 1990/11-1996/06 55.80E 21.10S $y=0.04+0.02 x ; N=153 ; R=0.36 ; P-$ value $<0.01$

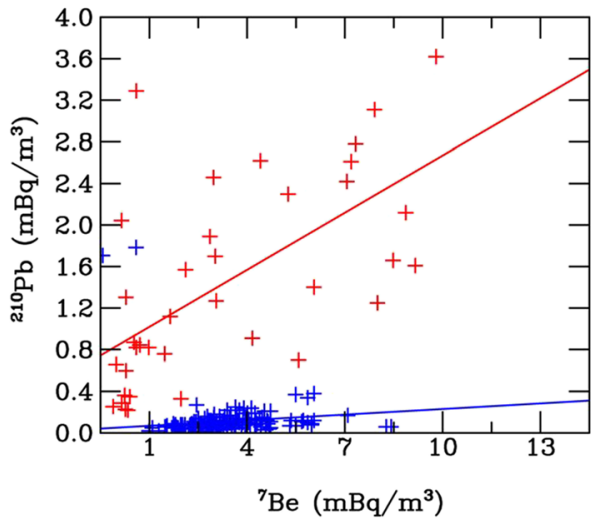

(c)

Nanning 2014/10-2017/12 108.45E 22.80N $\mathrm{y}=0.74+0.18 \mathrm{x} ; \mathrm{N}=74 ; \mathrm{R}=0.62 ; \mathrm{P}$-value $<0.01$ Australia Norfolk Is 1983/04-1994/08 167.95E 29.03S $\mathrm{y}=0.03+0.02 \mathrm{x} ; \mathrm{N}=555 ; \mathrm{R}=0.40 ; \mathrm{P}-$ value $<0.01$

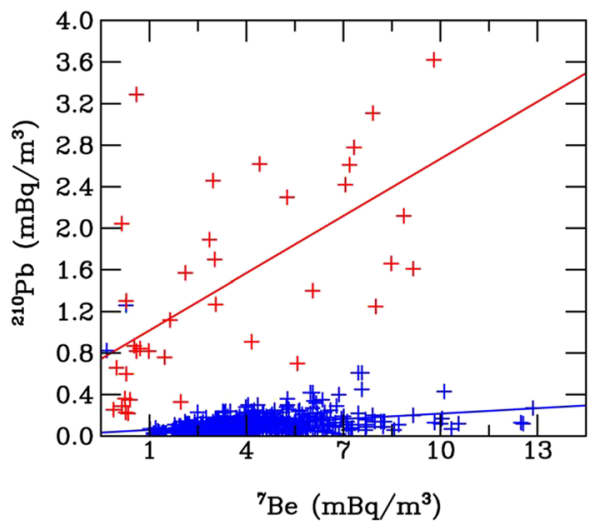

(e)

Nanning 2014/10-2017/12 108.45E 22.80N $\mathrm{y}=0.74+0.18 \mathrm{x} ; \mathrm{N}=74 ; \mathrm{R}=0.62 ; \mathrm{P}-$ value $<0.01$ Australia Perth***** 1982/11-1994/09 115.82E 31.97S $\mathrm{y}=0.12+0.05 \mathrm{x} ; \mathrm{N}=544 ; \mathrm{R}=0.36 ; \mathrm{P}-$ value $<0.01$

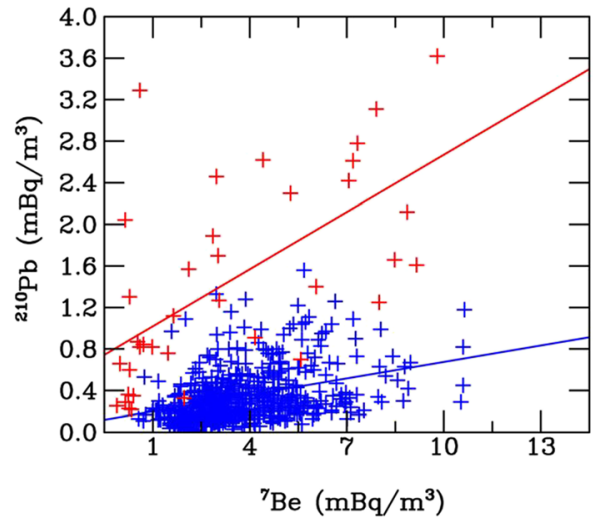

(b)

Data Period 2014/10-2017/12; Nanning $\mathrm{y}=2.34+2.26 \mathrm{x} ; \mathrm{N}=34 ; \mathrm{R}=0.40 ; \mathrm{P}-$ value $=0.0193$ France Reunion Islan 1990/11-1996/06 55.80E 21.10S $\mathrm{y}=3.73+0.97 \mathrm{x} ; \mathrm{N}=95 ; \mathrm{R}=0.14 ; \mathrm{P}-$ value $=0.1872$

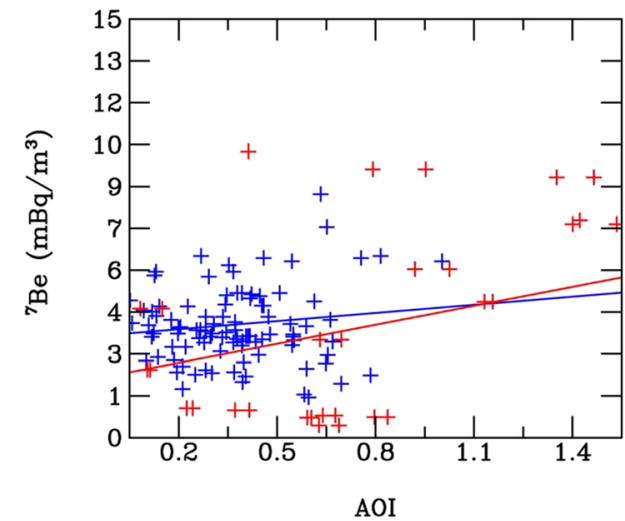

(d)

Data Period 2014/10-2017/12; Nanning $\mathrm{y}=2.34+2.26 \mathrm{x} ; \mathrm{N}=34 ; \mathrm{R}=0.40 ; \mathrm{P}$-value $=0.0193$ Australia Norfolk Is 1983/04-1994/08 167.95E 29.03S $\mathrm{y}=4.39+0.48 \mathrm{x} ; \mathrm{N}=301 ; \mathrm{R}=0.10 ; \mathrm{P}-$ value $=0.0701$

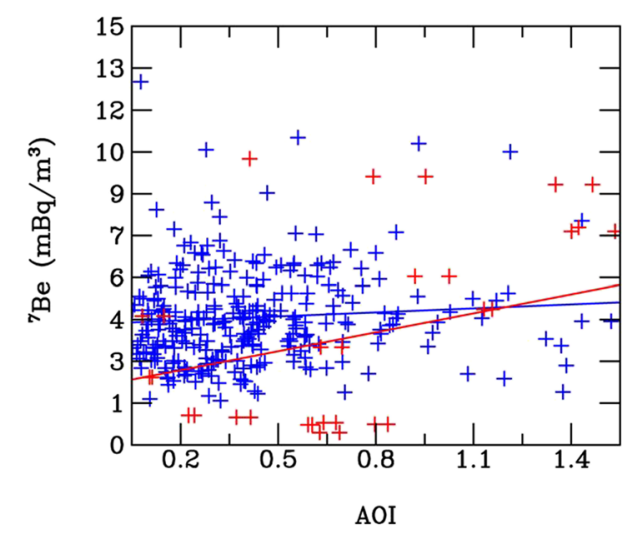

(f)

Data Period 2014/10-2017/12; Nanning

$\mathrm{y}=2.34+2.26 \mathrm{x} ; \mathrm{N}=34 ; \mathrm{R}=0.40 ; \mathrm{P}-$ value $=0.0193$ Australia Perth***** 1982/11-1994/09 115.82E 31.97S $\mathrm{y}=3.97+0.50 \mathrm{x} ; \mathrm{N}=297 ; \mathrm{R}=0.11 ; \mathrm{P}$-value $=0.0598$

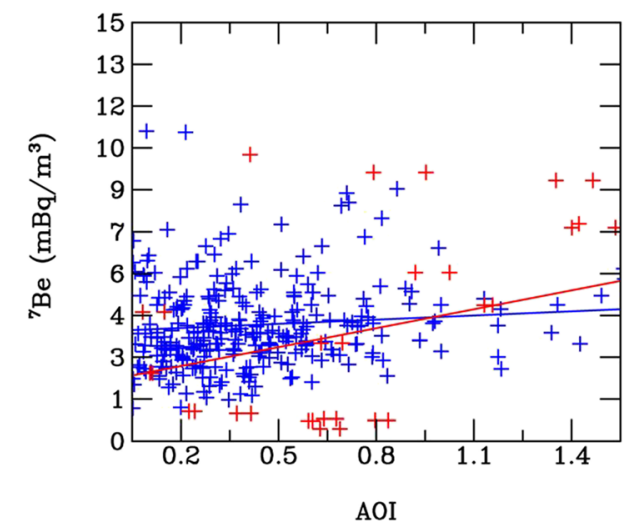

advection and the disturbance between the troposphere and stratosphere. As a tracer of the STE, the good coherence between ${ }^{7} \mathrm{Be}$ and ${ }^{210} \mathrm{~Pb}$ indicates that the disturbance of the air due to high mountains can promote the coupling of the 
Fig. 7 The same as Fig. 6, but for sites in the SH. Panels (a) and (b) are for Tasmania, Australia. Panels (c) and (d) are for Chatham, New Zealand. Panels (e) and (f) are for Mawson, Antarctica (a)

Nanning 2014/10-2017/12 108.45E 22.80N $\mathrm{y}=0.74+0.18 \mathrm{x} ; \mathrm{N}=74 ; \mathrm{R}=0.62 ; \mathrm{P}-$ value $<0.01$ Australia Tasmania C 1982/10-1998/01 144.77E 40.73S $\mathrm{y}=0.06+0.01 \mathrm{x} ; \mathrm{N}=585 ; \mathrm{R}=0.21 ; \mathrm{P}-$ value $<0.01$

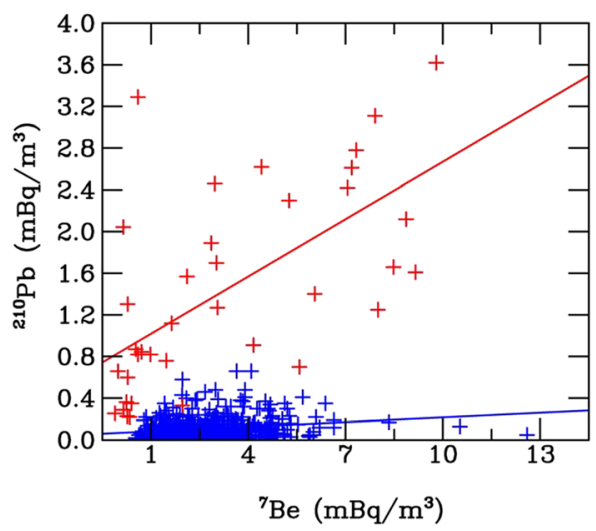

(c)

Nanning 2014/10-2017/12 108.45E 22.80N $\mathrm{y}=0.74+0.18 \mathrm{x} ; \mathrm{N}=74 ; \mathrm{R}=0.62 ; \mathrm{P}$-value $<0.01$

aland Chatham 1983/09-1994/06 176.00W 43.93S New Zealand Chatham 1983/09-1994/06 176.00W 43.93S $\mathrm{y}=0.02+0.01 \mathrm{x} ; \mathrm{N}=502 ; \mathrm{R}=0.37 ; \mathrm{P}$-value $<0.01 \quad \mathrm{y}=2.82+0.48 \mathrm{x} ; \mathrm{N}=270 ; \mathrm{R}=0.16 ; \mathrm{P}-$ value $=0.0106$

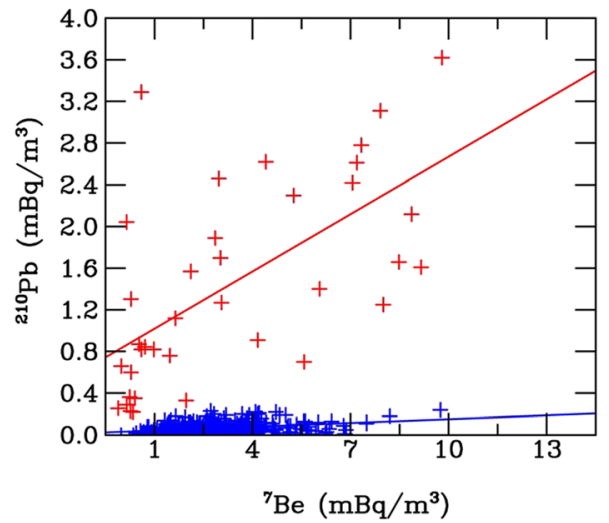

(e)

Nanning 2014/10-2017/12 108.45E 22.80N $\mathrm{y}=0.74+0.18 \mathrm{x} ; \mathrm{N}=74 ; \mathrm{R}=0.62 ; \mathrm{P}-$ value $<0.01$ Antarctica Mawson*** 1987/02-1998/01 62.88E 67.60S $\mathrm{y}=0.02+0.00 \mathrm{x} ; \mathrm{N}=216 ; \mathrm{R}=0.35 ; \mathrm{P}-$ value $<0.01$

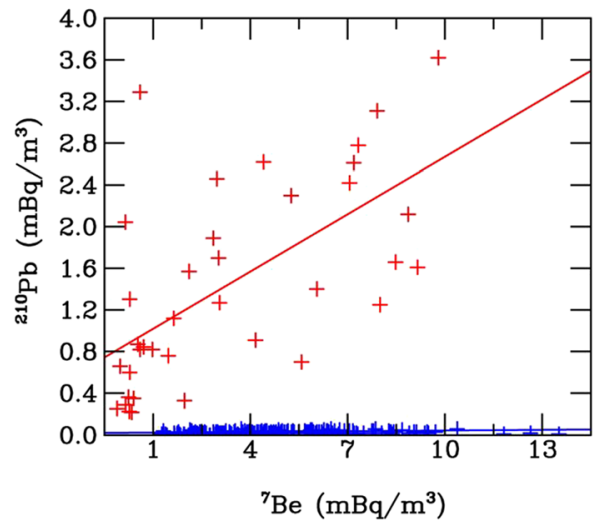

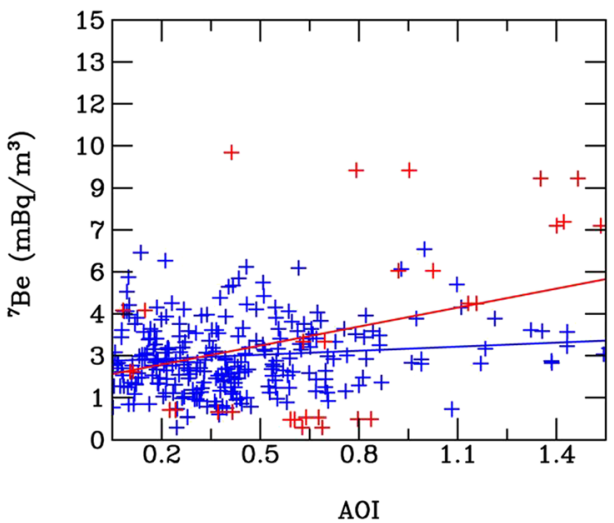

(f)

Data Period 2014/10-2017/12; Nanning $\mathrm{y}=2.34+2.26 \mathrm{x} ; \mathrm{N}=34 ; \mathrm{R}=0.40 ; \mathrm{P}$-value $=0.0193$ Antarctica Mawson*** 1987/02-1998/01 62.88E 67.60S $\mathrm{y}=4.10+2.10 \mathrm{x} ; \mathrm{N}=128 ; \mathrm{R}=0.29 ; \mathrm{P}-$ value $<0.01$

(b)

Data Period 2014/10-2017/12; Nanning $\mathrm{y}=2.34+2.26 \mathrm{x} ; \mathrm{N}=34 ; \mathrm{R}=0.40 ; \mathrm{P}$-value $=0.0193$ tralia Tasmania C 1982/10-1998/01 144.77E 40.73S $\mathrm{y}=2.92+0.37 \mathrm{x} ; \mathrm{N}=311 ; \mathrm{R}=0.11 ; \mathrm{P}-$ value $=0.0622$

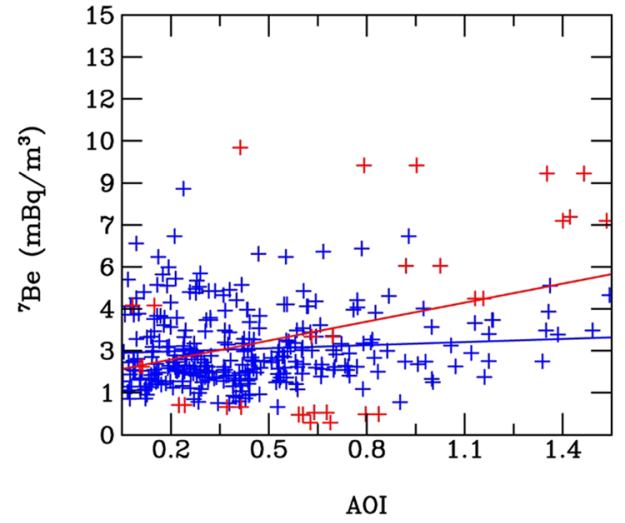

(d)

Data Period 2014/10-2017/12; Nanning

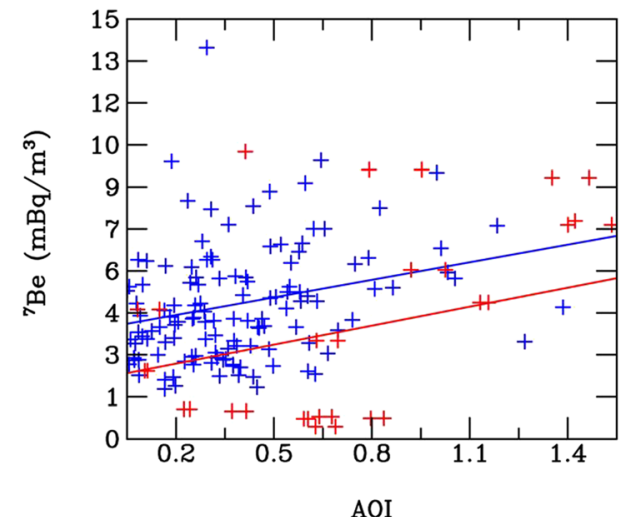

stratosphere and troposphere. Interestingly, Nanning exhibited correlations of both ${ }^{7} \mathrm{Be}$ versus $\mathrm{AOI}$ and ${ }^{210} \mathrm{~Pb}$ versus ${ }^{7} \mathrm{Be}$ that were higher than those at all the EML sites. Nanning is located in the westerly disturbance area on the leeward side of 
Fig. 8 Spatial distribution of EML sites with statistically significant correlations for the analyzed pairs: (a) ${ }^{7} \mathrm{Be}$ versus

${ }^{210} \mathrm{~Pb}$ and (b) AOI versus ${ }^{7} \mathrm{Be}$

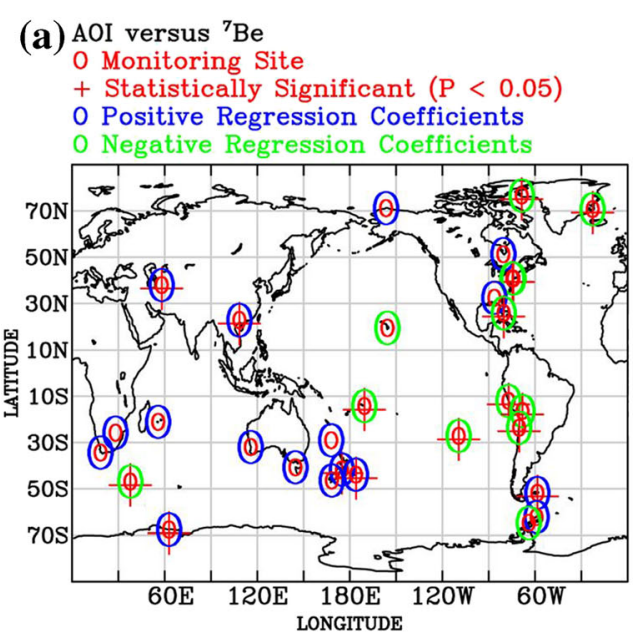

the Himalayas, which is the highest mountain range on Earth. Hawaii, affected by the Himalayas, is downwind of Nanning. Montgomery, Alabama, is on the east coast of the US and experiences a relatively severe air disturbance due to the Rocky Mountains. In Barrow, Alaska, which is affected by the Alaska Mountain Range, the correlations between ${ }^{210} \mathrm{~Pb}$ and ${ }^{7} \mathrm{Be}$ are also notable with $\mathrm{R}=0.59$ and a $P$ value $<0.01$, and the lower ${ }^{210} \mathrm{~Pb}$ activity may be due to its coastal location. The Montgomery site $\left(32^{\circ} \mathrm{N}\right)$ in Alabama exhibits a good correlation between ${ }^{210} \mathrm{~Pb}$ and ${ }^{7} \mathrm{Be}$, with $\mathrm{R}=0.49(P<0.01)$.

Figure $8(\mathrm{~b})$ shows the sites that exhibit statistical significance in the linear regression analysis of ${ }^{7} \mathrm{Be}$ versus ${ }^{210} \mathrm{~Pb}$. This figure shows the sites that are the most responsive and reflect the highest degree of coupling between the stratosphere and troposphere during the positive phases of the AO.

At these sites, the correlations between ${ }^{7} \mathrm{Be}$ and $\mathrm{AOI}$ and between ${ }^{210} \mathrm{~Pb}$ and ${ }^{7} \mathrm{Be}$ are significant with $P$-values that are less than 0.05; these sites include Barrow, Alaska and Montgomery, Alabama in the USA, and Perth and Tasmania in Australia. Note that Fig. 7(e) shows that both Nanning and Mawson Station in Antarctica have similar measurements of ${ }^{7} \mathrm{Be}$, but the ${ }^{210} \mathrm{~Pb}$ at Mawson is very low compared with that at Nanning. The higher ${ }^{210} \mathrm{~Pb}$ activity at the Nanning site is mainly due to its location in an inland city as well as industrial influence. Mawson Station in Antarctica, which is far from continents, has very low ${ }^{210} \mathrm{~Pb}$ activity due to the reduction (decay and diffusion) in ${ }^{210} \mathrm{~Pb}$ during long-distance ground dust transport from remote terrestrial areas. On the other hand, the elevated ${ }^{7} \mathrm{Be}$ over Mawson, Antarctica indicates the abundant sources of ${ }^{7} \mathrm{Be}$ from the lower stratosphere over Antarctica.

The good correlations between ${ }^{7} \mathrm{Be}$ and ${ }^{210} \mathrm{~Pb}$ represent the spatial distribution of observations dominated by stratospheretroposphere coupled effects (Fig. 8(b)). The good correlations between the $\mathrm{AOI}$ and ${ }^{7} \mathrm{Be}$ represent the spatial distribution of sites with the AO-initiated stratospheric effect in the troposphere (Fig. 8(a)). The combined good correlations of the paired AOI versus ${ }^{7} \mathrm{Be}$ and ${ }^{7} \mathrm{Be}$ versus ${ }^{210} \mathrm{~Pb}$ represent the AO-initialized stratosphere-troposphere coupled effect.

\section{Discussion and Conclusions}

In this work, we showed that the ground levels of ${ }^{7} \mathrm{Be}$ and ${ }^{210} \mathrm{~Pb}$ at the Nanning and EML stations in Alaska (Barrow), Montgomery (Alabama), Australia (Perth, Tasmania, and Norfolk), New Zealand (Chatham), and American Samoa were positively and statistically significantly correlated with an increase in the positive AOI. What are the mechanisms resulting in the surface ${ }^{7} \mathrm{Be}$ and ${ }^{210} \mathrm{~Pb}$ being positively correlated with the AOI? What processes that lead to ${ }^{7} \mathrm{Be}$ were positively correlated with ${ }^{210} \mathrm{~Pb}$ at these sites?

The production rates of ${ }^{7} \mathrm{Be}$ are higher in the upper troposphere and lower stratosphere $\left(25-50{ }^{7} \mathrm{Be}\right.$ atoms s${ }^{-1}$ (gram of air) ${ }^{-1}$ ) than in the lower troposphere $\left(1-5^{7} \mathrm{Be}\right.$ atoms s ${ }^{-1}$ (gram of air) ${ }^{-1}$; Koch et al. 1996). Approximately two-thirds of the ${ }^{7} \mathrm{Be}$ is produced in the stratosphere, and one-third of the ${ }^{7} \mathrm{Be}$ is produced in the troposphere (Rehfeld and Heimann 1995). On the other hand, ${ }^{210} \mathrm{~Pb}$ is produced from the radioactive decay of ${ }^{222} \mathrm{Rn}$, which is released from terrestrial soil (Koch et al. 1996). Hence, only a small contribution of stratospheric air is needed to produce a large change in the observed ${ }^{7} \mathrm{Be}$ in surface air (Dutkiewicz and Husain, 1985).

Figure 9 shows the difference in geopotential height $(\mathrm{m})$ at $850 \mathrm{hPa}$ between years of positive AO $(1989,1990,1992$, 1993, 1997, and 2000) and years of negative AO (1980, 1985, 1987, and 2001) calculated by Lamarque and Hess (2004). The positive geopotential anomalies are associated with the positive anomalies of high pressures and clockwise circulations. Red curves encircle the regions of the anomalous highs with high pressure centers highlighted by $\mathrm{H}_{1}, \mathrm{H}_{2}, \mathrm{H}_{3}$, and $\mathrm{H}_{4} \cdot \mathrm{H}_{1}$ is centered at approximately $120^{\circ} \mathrm{E}$ and $45^{\circ} \mathrm{N}$ (eastern Asian continent). $\mathrm{H}_{2}$ is centered around the North Pacific, at $150^{\circ} \mathrm{W}$ and $60^{\circ} \mathrm{N}$. The high-pressure systems are 


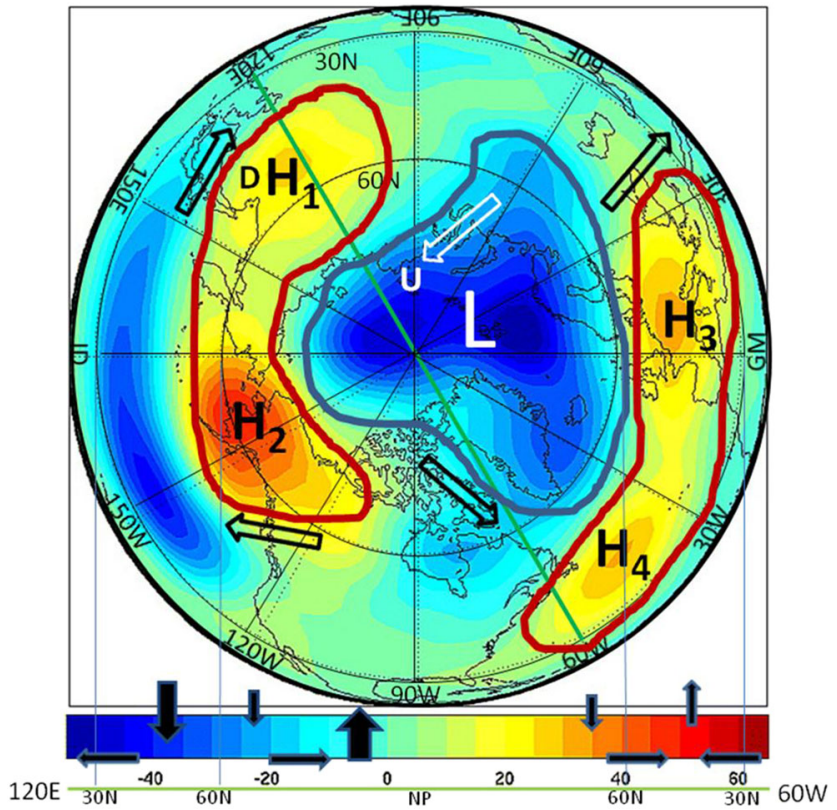

Fig. 9 A schematic diagram showing the distribution of the anomalous high- and low-pressure systems associated with differences between the positive and negative $\mathrm{AO}$ years. The shaded colors indicate the distribution of the anomalous high (red) and low (blue) pressure systems adapted from Lamarque and Hess (2004). The locations of the high-pressure systems are indicated by $\mathrm{H}_{1}, \mathrm{H}_{2}, \mathrm{H}_{3}$, and $\mathrm{H}_{4}$. Schematic flow symbols indicate that the main low-pressure system, L, over the Arctic regions is added to demonstrate the flow patterns associated with the anomalous high- and low-pressure systems. The bottom panel shows a meridional vertical circulation through the $120^{\circ} \mathrm{E}$ and $60^{\circ} \mathrm{W}$ cross-sections (indicated by the green line in the upper panel) associated with the anomalous highand low-pressure systems

accompanied by subsidence flow from the upper troposphere to the lower stratosphere. The lower panel of Fig. 9 shows vertical circulations associated with the anomalous high- and low-pressure systems. Hence, high-pressure systems are associated with enhanced subsidence (Lee et al. 2004). They are conducive to the vertical transport of elevated ${ }^{7} \mathrm{Be}$ from the upper troposphere and lower stratosphere (UTLS) regions to the lower troposphere. The subsidence associated with highpressure systems also suppresses convection and precipitation processes in the atmospheric boundary layer, leading to the enhancement of ${ }^{210} \mathrm{~Pb}$ at the surface (Rehfeld and Heimann 1995; Koch et al. 1996; Wang et al. 1999). Hence, the development of the positive AOI is conducive to the transport of elevated ${ }^{7} \mathrm{Be}$ from the UTLS regions to the lower troposphere.

The negative differences in the AOI are associated with the negative anomalies of the low pressure and anti-clockwise circulations. They are associated with enhanced upward motion. The development of the anomalous low-pressure system, L, over the Arctic region acts to enhance the strength of the polar vortex (Thompson and Wallace 1998; Baldwin and Dunkerton 1999; Ambaum and Hoskins 2002). A developing polar vortex produces atmospheric circulations similar to those of the AO patterns in Fig. 9 and is conducive for the
STE and downward transport of elevated potential vorticity (PV) and ${ }^{7} \mathrm{Be}$ to the lower troposphere (Black 2002; James et al. 2003).

The Nanning site is located downstream of the $\mathrm{H}_{1}$ highpressure system, while the $\mathrm{H}_{2}$ high-pressure system influences the Barrow site in Alaska during the positive AO phases. The rest of the sites (Mauna Loa, three sites in Australia, two sites in New Zealand, and American Samoa) are located in regions with enhanced subsidence during the positive AO phases (Limpasuvan et al. 2005; Zhao and Miller 2005).

The HYSPLIT model calculations show that the back trajectories tend to originate in the high altitudes of the troposphere and with the origins of the trajectories in northern higher latitudes. These results are presented in the regression model analysis (altitudes are correlated with latitudes). The clockwise back trajectories are consistent with the subsidence of the flows associated with the high-pressure systems from northern high latitudes and high altitudes to the tropical Nanning site.

We used NCEP reanalysis data to check the sensitivity of the HYSPLIT results with respect to the meteorological data used in this work. Fig. S2 compares the horizontal distribution of the back trajectories calculated with the GDAS0p5 data (Fig. S2(a)) and with the NCEP reanalysis data (Fig. S2(b)). We note that the GDAS0p5 data have a horizontal resolution of 0.5 degrees longitude-latitude and contain output data collected every $3 \mathrm{~h}$ on 55 hybrid sigma-pressure levels from the surface to $13 \mathrm{hPa}$. The reanalysis data have a horizontal resolution of a 2.5 degree longitude-latitude grid, output data collected every $6 \mathrm{~h}$, and 17 pressure levels $(1000,925,850,700$, $600,500,400,300,250,200,150,100,70,50,30,20$, and $10 \mathrm{hPa}$ ). Fig. S2 shows that the general patterns of the gridded distribution of the occurrence of back trajectories are similar. However, the results calculated with GDAS0p5 data show a more widespread distribution of the back trajectories than the results calculated with the reanalysis data. The GDAS0p5 data have a higher horizontal and vertical resolution than the reanalysis data, resulting in a better representation of the vertical velocity. The linear regression analysis of the $\mathrm{AOI}$ and ${ }^{7} \mathrm{Be}$ versus latitudes and altitudes calculated with the reanalysis data are consistent with the results calculated with the GDAS0p5 data. Elevated AOIs are associated with air originating from northern higher latitudes (Fig. S3(a)). Elevated ${ }^{7} \mathrm{Be}$ is associated with air originating from northern higher latitudes (Fig. S3(b)). The air from northern higher latitudes originates from elevated altitudes (Fig. S3(c)). Elevated AOIs are associated with air from higher altitudes (Fig. S3(d)). Elevated ${ }^{7} \mathrm{Be}$ concentrations are associated with air originating from higher altitudes (Fig. S3(e)). The altitudinal origins of the air calculated with the reanalysis data are mostly limited to altitudes below $5 \mathrm{~km}$ (Fig. S3(d)), which are lower than the origins of the air calculated with the GDAS0p5 data (Fig. 4(d)). These comparisons indicate that the vertical velocities 
calculated from the coarse resolution of the reanalysis data are lower than the high resolution of the GDAS0p5 data. A separate study has evaluated the quality of the GDAS0p5 data for back trajectory studies over East Asia. The calculations show that elevated CO concentrations over North Pacific flight corridors can be traced back to the ground level industrial areas over East Asia. In contrast, the back trajectories show that low $\mathrm{CO}$ in the upper troposphere is associated only with the air in the upper troposphere, where the $\mathrm{CO}$ concentrations are low.

We note that Nanning has abundant precipitation leading to wet summers, and rainfall is the main removal process of aerosols from the atmosphere. Therefore, the influence of removal of rainfall on radionuclides in aerosols should be taken into account. Therefore, in Fig. 3(b), we considered the correlation analysis of rainfall on the activity of the three nuclides. The negative correlations shown in Fig. 3(b) are consistent with previous works (e.g., Rehfeld and Heimann 1995; Koch et al. 1996), showing the wet scavenging effect of ${ }^{7} \mathrm{Be}$ and ${ }^{210} \mathrm{~Pb}$ in Nanning.

The dynamics of recent climate change have been linked to the Arctic (e.g., James et al. 2003). The North Atlantic Oscillation (NAO) and AO have become more positively biased since 1950 (e.g., Visbeck et al. 2001; Hurrell et al. 2004). As shown in this study, the levels of near-surface ${ }^{7} \mathrm{Be}$ and ${ }^{210} \mathrm{~Pb}$ are positively correlated with the increasing trends in the positive AO. Continuous measurements of near-surface ${ }^{7} \mathrm{Be}$ and ${ }^{210} \mathrm{~Pb}$ can provide radioactive evidence for monitoring continuous changes in the $\mathrm{AO}$ and the links to global warming.

Based on previous works (Wang et al. 2002; Wang and Kau 2015 and references therein; and references cited in the manuscript), we use the association between ground-level observed ${ }^{7} \mathrm{Be}$ (a stratospheric tracer) and the AOI to indicate the changes in the STE associated with the AOI in this work. The air with stratospheric origins contains elevated ${ }^{7} \mathrm{Be}$, elevated $\mathrm{O}_{3}$, low $\mathrm{CO}$, and low $\mathrm{H}_{2} \mathrm{O}$. Hence, we also analyze $\mathrm{O}_{3}, \mathrm{H}_{2} \mathrm{O}$, and temperature from ozonesonde measurements (WOUDC 2021). Fig. S4 shows the linear regression model analysis of $\mathrm{O}_{3}, \mathrm{H}_{2} \mathrm{O}$, and temperature versus $\mathrm{AOI}$ at three sites over the North Pacific from 2014 to 2017. At an altitude of $3 \mathrm{~km}$ (to reduce the impact of ground-level photochemical $\mathrm{O}_{3}$ production), increases in $\mathrm{O}_{3}$ are associated with increases in the AOI at Taipei $\left(25.00^{\circ} \mathrm{N}, 121.44^{\circ} \mathrm{E}\right.$; Fig. S4(a)), Hong Kong $\left(22.31^{\circ} \mathrm{N}, 114.17^{\circ} \mathrm{E}\right.$; Fig. S4(d)), and Hilo, Hawaii $\left(19.43^{\circ} \mathrm{N}, 155.04^{\circ} \mathrm{W}\right.$; Fig. S4(g)). In contrast, decreases in $\mathrm{H}_{2} \mathrm{O}$ are associated with increases in the AOI at Taipei (Fig. S4(b)) and Hong Kong (Fig. S4(e)). $\mathrm{H}_{2} \mathrm{O}$ at Hilo (Fig. S4(h)) was compounded by $\mathrm{H}_{2} \mathrm{O}$ evaporation from the underlying ocean. Additionally, an increase in AOIs are associated with decreases in temperature in Taipei (Fig. S4(c)), Hong Kong (Fig. S4(f)), and Hilo (Fig. S4(i)). Fig. S5 shows regression analysis profiles throughout the troposphere, from the surface to an altitude of $10 \mathrm{~km}$, with respect to increases in the AOI. At Taipei, $\mathrm{O}_{3}$ increases at altitudes of $3 \mathrm{~km}$ and above $5 \mathrm{~km}$
(Fig. S5(a)), and decreases in $\mathrm{H}_{2} \mathrm{O}$ (Fig. S5(b)) and temperature (Fig. S5(c)) occur in the troposphere. At Hong Kong, $\mathrm{O}_{3}$ increases at altitudes below $7 \mathrm{~km}$ (Fig. S5(d)), and decreases in $\mathrm{H}_{2} \mathrm{O}$ (Fig. S5(e)) and temperature (Fig. S5(f)) occur in the troposphere. Hong Kong is located $580 \mathrm{~km}$ east of the Nanning site. Hong Kong has ozonesonde data that is closest to the Nanning site. In the middle of the North Pacific Hilo site, $\mathrm{O}_{3}$ increases at altitudes below $4 \mathrm{~km}$ and above $6 \mathrm{~km}$ in the troposphere (Fig. $\mathrm{S} 5(\mathrm{~g})$ ), $\mathrm{H}_{2} \mathrm{O}$ decreases at altitudes below $2 \mathrm{~km}$ (Fig. S5(h)), and temperature decreases throughout the troposphere (Fig. S5(i)).

We also used ozonesonde data from Hong Kong to test the sensitivity of the regression results when seasonal cycles were excluded. The ${ }^{7} \mathrm{Be}$ data cover 4 winters $(2014,2015,2016$, and 2017), while the ozonesonde data in Hong Kong cover a period of 20 years (2000-2020) and have 20 winters for analysis. Fig. S5(d), (e), and (f) demonstrate that the profiles of $\mathrm{O}_{3}$ and $\mathrm{H}_{2} \mathrm{O}$ trends and the increases in the $\mathrm{AO}$ over Hong Kong are consistent with the trends of $7 \mathrm{Be}$ that vary with $\mathrm{AO}$ over Nanning during the analysis period (December 2014December 2017). Analysis of the 20 years of data shows that $\mathrm{O}_{3}$ increased as the $\mathrm{AO}$ increased at altitudes below $7 \mathrm{~km}$ (Fig. $\mathrm{S} 6(\mathrm{a})), \mathrm{H}_{2} \mathrm{O}$ decreased as the $\mathrm{AO}$ increased at altitudes below $7 \mathrm{~km}$ (Fig. S6(b)), and temperature decreased as the AO increased throughout the troposphere (Fig. S6(c)). When data only from the winter months (December, January, and February) are considered in the analysis, the results show that increases in $\mathrm{O}_{3}$ occur with increases in the $\mathrm{AO}$ at altitudes below $3 \mathrm{~km}$ (Fig. S6(d)), and decreases in $\mathrm{H}_{2} \mathrm{O}$ occur with increases in the $\mathrm{AO}$ at altitudes below $3 \mathrm{~km}$ (Fig. S6(e)). Hence, the results in the lower troposphere show that the $\mathrm{O}_{3}$ and $\mathrm{H}_{2} \mathrm{O}$ changes with the increases in $\mathrm{AO}$ are consistent between all data and winter-only data. Fig. S6(f) shows that temperatures are slightly increased in the troposphere with increases in the AO. This result is consistent with a longer trend of increases in tropospheric temperatures associated with global warming.

Supplementary Information The online version contains supplementary material available at https://doi.org/10.1007/s13143-021-00237-2.

Acknowledgments We gratefully acknowledge the NOAA Air Resources Laboratory (ARL) for providing the HYSPLIT transport and dispersion model and/or the READY website http://www.arl.noaa.gov/ ready.html used in this publication; the United States (US) Environmental Measurements Laboratory (EML) for the global observational data (https://www.wipp.energy.gov/NAMP/EMLLegacy/databases.htm); the United Kingdom Meteorological Office (UKMO) Hadley Centre HadISD version 3.1.0.201911p for the precipitation data (https://www. metoffice.gov.uk/hadobs/hadisd/v310 201911p/download.html); the cosmic ray station of the Sodankyla Geophysical Observatory, University of Oulu, Finland, for the cosmic ray data (https://cosmicrays. oulu.fi/); and the China Earthquake Networks Center for the earthquake data (https://www.cenc.ac.cn/). The EML sample archives make 
available environmental radiological data collected for programs funded through the U.S. Atomic Energy Commission, the U. S. Energy Research and Development Administration and the U. S. Department of Energy. All of these programs have been terminated. The databases were last updated in 1999. No additional data will be added to these databases. Any inquiries about these programs should be made to webmaster@ eml.st.dhs.gov. We greatly benefited from the sampling support and data provided by the Radiation-Environment Management and Monitoring Station of the Guangxi Zhuang Autonomous Region, Nanning 530222, China (http://nnsa.mee.gov.cn/zjjg/pcjg/201501/ t20150107_305223.html; https://sthjt.gxzf.gov.cn). The Nanning data reported in this work are shown in Table 1. KYW was funded under 108-2111-M-008-034

Open Access This article is licensed under a Creative Commons Attribution 4.0 International License, which permits use, sharing, adaptation, distribution and reproduction in any medium or format, as long as you give appropriate credit to the original author(s) and the source, provide a link to the Creative Commons licence, and indicate if changes were made. The images or other third party material in this article are included in the article's Creative Commons licence, unless indicated otherwise in a credit line to the material. If material is not included in the article's Creative Commons licence and your intended use is not permitted by statutory regulation or exceeds the permitted use, you will need to obtain permission directly from the copyright holder. To view a copy of this licence, visit http://creativecommons.org/licenses/by/4.0/.

\section{References}

Ambaum, M.H., Hoskins, B.J.: The NAO troposphere-stratosphere connection. J. Clim. 15, 1969-1978 (2002)

Baldwin, M.P., Dunkerton, T.J.: Propagation of the Arctic oscillation from the stratosphere to the troposphere. J. Geophys. Res. 104(D24), 30,937-30,946 (1999)

Balkanski, Y.J., Jacob, D.J., Gardner, G.M., Graustein, W.C., Turekian, K.K.: Transport and residence times or tropospheric aerosols inferred from a global three-dimensional simulation of ${ }^{210} \mathrm{~Pb}$. J. Geophys. Res. 98, 20573-20586 (1983)

Baskaran, M.: ${ }^{210} \mathrm{Po}$ and ${ }^{210} \mathrm{~Pb}$ as atmospheric tracers and global ${ }^{210} \mathrm{~Pb}$ fallout: a review. J. Environ. Radioact. 102, 500-513 (2011)

Baskaran, M., Shaw, G.E.: Residence time of arctic haze aerosols using the concentrations and activity ratios of ${ }^{210} \mathrm{Po},{ }^{210} \mathrm{~Pb}$ and $7 \mathrm{Be}$. J. Aerosol Sci. 32(4), 443-452 (2001). https://doi.org/10.1016/ S0021-8502(00)00093-8

Bhandari, N., Lal, D.: Vertical structure of the troposphere as revealed by radioactive tracer studies. J. Geophys. Res. 75, 2974-2980 (1970)

Black, R.X.: Stratospheric forcing of surface climate in the artic oscillation. J. Clim. 15(1), 268-277 (2002)

Bonasoni, P., Evanegelisti, F., Boanfé, U., Feldmann, H., Memmesheimer, M., Stohl, A., Tositti, L.: Stratospheretroposphere exchanges: case studies recorded at Mt. Cimone during VOTALP project. Physics and Chemistry of the Earth, Parts C. 24(5), 443-446 (1999)

Bonasoni, P., Evangelisti, F., Bonafé, U., Ravegnani, F., Calzolari, F., Stohl, A., Tositti, L., Tubertini, O., Colombo, T.: Stratospheric ozone intrusion episodes recorded at Mt. Cimone during VOTALP project: case studies. Atmos. Environ. 34, 1355-1365 (2000a)

Bonasoni, P., Stohl, A., Cristofanelli, P., Calzolari, F., Colombo, T., Evangelisti, F.: Background ozone variations at Mt Cimone station. Atmos. Environ. 34, 5183-5189 (2000b)

Bondietti, E.A., Papastefanou, C., Rangarajan, C.: Aerodynamic size associations of natural radioactivity with ambient aerosols. In: Hopke, P.K. (ed.) Radon and is decay products: occurrence, properties and health effects, ACS Symposium Series, 331, pp. 377-397. American Chemical Society, Washington, D.C. (1987)

Bourcier, L., Masson, O., Laj, P., Pichon, J.M., Paulat, P., Freney, E., Sellegri, K.: Comparative trends and seasonal variation of $7 \mathrm{Be}$, $210 \mathrm{~Pb}$ and $137 \mathrm{Cs}$ at two altitude sites in the central part of France. J. Environ. Radioact. 102(3), 294-301 (2011)

Bronson, F.L.: Validation of the accuracy of the LabSOCS software for mathematical efficiency calibration of Ge detectors for typical laboratory samples. J. Radioanal. Nucl. Chem. 255(1), 137-141 (2003)

Brost, R.A., Feichter, J., Heimann, M.: Three-dimensional modeling of the concentration and deposition of ${ }^{210} \mathrm{~Pb}$ aerosols. J. Geophys. Res. 96, 22,423-22,445 (1991)

Carvalho, F.P.: Origins and concentrations of ${ }^{222} \mathrm{Rn},{ }^{210} \mathrm{~Pb},{ }^{210} \mathrm{Bi}$ and ${ }^{210} \mathrm{Po}$ in the surface air at Lisbon, Portugal, at the Atlantic edge of the European continental landmass. Atmos. Environ. 29(15), 18091819 (1995)

Chen, W., Lan, X.Q., Wang, L., Ma, Y.: The combined effects of the ENSO and the Arctic oscillation on the winter climate anomalies in East Asia. Chin. Sci. Bull. 58(12), 1355-1362 (2013). https://doi. org/10.1007/s11434-012-5654-5

Cristofanelli, P., Bonasoni, P., Tositti, L., Bonafé, U., Calzolari, F., Evangelisti, F., Sandrini, S., Stohl, A.: A 6-year analysis of stratospheric intrusions and their influence on ozone at Mt. Cimone (2165 m above sea level). J. Geophys. Res. 111, D03306 (2006). https:// doi.org/10.1029/2005JD006553

Cristofanelli, P., Bonasoni, P., Carboni, G., Calzolari, F., Casarola, L., Zauli Sajani, S., Santaguida, R.: Anomalous high ozone concentrations recorded at a high mountain station in Italy in summer 2003. Atmos. Environ. 41, 1383-1394 (2007)

Cristofanelli, P., Calzolari, F., Bonafé, U., Duchi, R., Marinoni, A., Roccato, F., Tositti, L., Bonasoni, P.: Stratospheric intrusion index (SI2) from baseline measurement data. Theor. Appl. Climatol. 97, 317-325 (2009)

Cutlip, K.: Northern influence. Weatherwise. 53(2), 10-11 (2000)

Daish, S.R., Dale, A.A., Dale, C.J., May, R., Rowe, J.E.: The temporal variations of $7 \mathrm{Be},{ }^{210} \mathrm{~Pb}$ and ${ }^{210} \mathrm{Po}$ in air in England. J. Environ. Radioact. 84(3), 457-467 (2005). https://doi.org/10.1016/j.jenvrad. 2005.05.003

Deng, Q., Wei, Y., Zhao, Y., Han, X., Yin, J.: Understanding the natural and socioeconomic factors behind regional longevity in Guangxi, China: Is the centenarian ratio a good enough indicator for assessing the longevity phenomenon? Int. J. Environ. Res. Public Health. 15(5), pii: E938 (2018). https://doi.org/10.3390/ijerph15050938

Dibb, J.E., Talbot, R.W., Gregory, G.L.: Beryllium 7 and lead 210 in the western hemisphere Arctic atmosphere: observations from three recent aircraft-based sampling pograms. J. Geophys. Res. 97(D15), 16709 (1992). https://doi.org/10.1029/91jd01807

Done, L., Tugulan, L.C., Gurau, D., Dragolici, F., Alexandru, C.: Comparison of LabSOCS and GESPECOR codes used in gammaray spectrometry. International Conference on Radionuclide Metrology \& Its Applications. 109, 539-543 (2016)

$\mathrm{Du}$, J., Baskaran, M., Du, J.: Atmospheric deposition of ${ }^{7} \mathrm{Be},{ }^{210} \mathrm{~Pb}$ and ${ }^{210} \mathrm{Po}$ during typhoons and thunderstorm in Shanghai, China and global data synthesis. Sci. China Earth Sci. 63(4), 602-614 (2020). https://doi.org/10.1007/s11430-019-9481-9

Dueñas, C., Orza, J.A.G., Cabello, M., Fernández, M.C., Cañete, S., Pérez, M., Gordo, E.: Air mass origin and its influence on radionuclide activities $\left({ }^{7} \mathrm{Be}\right.$ and $\left.{ }^{210} \mathrm{~Pb}\right)$ in aerosol particles at a coastal site in the western Mediterranean. Atmos. Res. 101(1-2), 205-214 (2011). https://doi.org/10.1016/j.atmosres.2011.02.011

Dunn, R. J. H., Willett, K.M., Thorne, P.W., Wooley, E.V., Durre, I., Dai., A., et al. (2012). HadISD: a quality-controlled global synoptic report database for selected variables at long-term stations from 1973-2011, Clim. Past, 8, 1649-1679, https://doi.org/10.5194/cp8-1649-2012 
Dunn, R.J.H., Willett, K.M., Morice, C.P., Parker, D.E.: Pairwise homogeneity assessment of HadISD. Clim. Past. 10, 1501-1522 (2014). https://doi.org/10.5194/cp-10-1501-2014

Dunn, R.J.H., Willett, K.M., Parker, D.E., Mitchell, L.: Expanding HadISD: quality-controlled, sub-daily station data from 1931. Geoscientific Instrumentation Methods and Data Systems. 5, 473491 (2016). https://doi.org/10.5194/gi-5-473-2016

Dutkiewicz, V. A., \& Husain, L. (1985). Stratospheric and tropospheric component of 7Be in surface air. J. Geophys. Res. 90, 5783-5788.

Feely, H.W., Larsen, R.J., Sanderson, C.G.: Factors that cause seasonal variations in Beryllium-7 concentrations in surface air. J. Environ. Radioact. 9(3), 223-249 (1989). https://doi.org/10.1016/0265931X(89)90046-5

Gong, D.Y., Wang, S.W., Zhu, J.H.: East Asian winter monsoon and Arctic oscillation. Geophys. Res. Lett. 28, 2073-2076 (2001)

Graustein, W.C., Turekian, K.K.: ${ }^{7} \mathrm{Be}$ and ${ }^{210} \mathrm{~Pb}$ indicate an upper troposphere source for elevated ozone in the summertime subtropical free troposphere of the eastern North Atlantic. Geophys. Res. Lett. 23, 539-542 (1996)

Grossi, C., Ballester, J., Serrano, I., Galmarini, S., Camacho, A., Curcoll, R., Morguí, J.A., Rodò, X., Duch, M.A.: Influence of long-range atmospheric transport pathways and climate teleconnection patterns on the variability of surface ${ }^{210} \mathrm{~Pb}$ and ${ }^{7} \mathrm{Be}$ concentrations in southwestern Europe. J. Environ. Radioact. 165, 103-114 (2016)

Holton, J.R., Haynes, P.H., McIntyre, M.E., Douglass, A.R., Pfister, L.: Stratosphere-troposphere exchange. Rev. Geophys. 33(4), 403-439 (1995)

Hoskins, B.J., McIntyre, M.E., Robertson, A.W.: On the use and significance of isentropic potential vorticity maps. Q. J. R. Meteorol. Soc. 111, 877-946 (1985)

Hotzl, H., Winkler, R.: Activity concentrations of ${ }^{226} \mathrm{Ra},{ }^{228} \mathrm{Ra},{ }^{210} \mathrm{~Pb},{ }^{40} \mathrm{~K}$ and ${ }^{7} \mathrm{Be}$ and their temporal variations in surface air. J. Environ. Radioact. 5, 445-5,458 (1987)

Huh, C.A., Su, C.C.: Sedimentation dynamics in the East China Sea elucidated from ${ }^{210} \mathrm{~Pb},{ }^{137} \mathrm{Cs}$ and ${ }^{239,240} \mathrm{Pu}$. Mar. Geol. 160(1-2), 183-196 (1999). https://doi.org/10.1016/S0025-3227(99)00020-1

Hurrell, J.W.: Decadal trends in the North Atlantic oscillation region temperatures and precipitation. Science. 269, 676-679 (1995)

Hurrell, J. W., Kushnir, Y., Ottersen, G., \& Visbeck, M. (2003). The North Atlantic oscillation: climate significance and environmental impact. Geophysical monograph series, vol. 134, AGU, Washington, D. C

Hurrell, J., Hoerling, M.P., Phillips, A.S., Xu, T.: Twentieth century North Atlantic climate change. Part 1: assessing determinism. Clim. Dyn. 23, 371-389 (2004)

James, P., Stohl, A., Forster, C., Eckhardt, S., Seibert, P., Frank, A.: A 15year climatology of stratosphere-troposphere exchange with a Lagrangian particle dispersion model. 2. Mean climate and seasonal variability. J. Geophys. Res. 108(D12), 8522 (2003). https://doi.org/ 10.1029/2002JD002639

Jaworowski, Z., Kownacka, L., Bysiek, M.: Global distribution and sources of uranium, Radium-226, and Lead-210. In: Natural Radiation Environment III, vol. 1, pp. 383-404. Technical Information Center, US Dept of Energy, Springfield (1980)

Jeong, J.H., Ho, C.H.: Changes in occurrence of cold surges over East Asia in association with Arctic oscillation. Geophys. Res. Lett. 32, L14704 (2005)

Jevrejeva, S., Moore, J.: Singular spectrum analysis of Baltic Sea ice conditions and large-scale atmospheric patterns since 1708 . Geophys. Res. Lett. 28(23), 4503-4506 (2001)

Johnson, W., Viezee, W.: Stratospheric ozone in the lower troposphere: i. presentation and interpretation of aircraft measurements. Atmos. Environ. 15, 1309-1323 (1981)

Koch, D.M., Jacob, D.J., Graustein, W.C.: Vertical transport of tropospheric aerosols as indicated by ${ }^{7} \mathrm{Be}$ and ${ }^{210} \mathrm{~Pb}$ in a chemical tracer model. J. Geophys. Res. Atmos. 101(13), 18651-18666 (1996). https://doi.org/10.1029/96jd01176

Lal, D., \& Peters, B. (1967). Cosmic ray produced radioactivity on the Earth. In: Sitte K. (Eds) Kosmische Strahlung II / Cosmic Rays II. Handbuch der Physik / Encyclopedia of Physics, Vol 9 / 46 / 2. Springer, Berlin, Heidelberg

Lamarque, J.-F., Hess, P.G.: Arctic oscillation modulation of the northern hemisphere spring tropospheric ozone. Geophys. Res. Lett. 31(6), L06127 (2004). https://doi.org/10.1029/2003g1019116

Larsen, R.J., Sanderson, C.G., \& Kada, J. (1995). EML surface air sampling program, 1990-1993 data. EML Report 572, 37-40, Environmental Measurements Laboratory, U.S. Department of Energy, New York

Lee, H.N., Wan, G., Zheng, X., Sanderson, C.G., Josse, B., Wang, et al.: Measurements of ${ }^{210} \mathrm{~Pb}$ and ${ }^{7} \mathrm{Be}$ in China and their analysis accompanied with global model calculations of ${ }^{210} \mathrm{~Pb}$. J. Geophys. Res. 109, D22203 (2004). https://doi.org/10.1029/2004JD005061

Lee, H.N., Tositti, L., Zheng, X., Bonasoni, P.: Analyses and comparisons of variations of ${ }^{7} \mathrm{Be},{ }^{210} \mathrm{~Pb}$, and ${ }^{7} \mathrm{Be} /{ }^{210} \mathrm{~Pb}$ with ozone observations at two global atmosphere watch stations from high mountains. J. Geophys. Res. 112, D05303 (2007). https://doi.org/10.1029/ 2006JD007421

Leppänen, A.P., Pacini, A.A., Usoskin, I.G., Aldahan, A., Echer, E., Evangelista, H., Klemola, S., Kovaltsov, G.A., Mursula, K., Possnert, G.: Cosmogenic ${ }^{7} \mathrm{Be}$ in air: a complex mixture of production and transport. J. Atmos. Sol. Terr. Phys. 72(13), 1036-1043 (2010). https://doi.org/10.1016/j.jastp.2010.06.006

Li, Y., Geng, X.C.: Effect of sample thickness on determination of ${ }^{137} \mathrm{Cs}$ and ${ }^{236} \mathrm{~Pb}$ using LabSOCS. Atomic Energy ence \& Technology. 44(1), 80-83 (2010)

Limpasuvan, V., Hartmann, D.L., Thompson, D.W.J., Jeev, K., Yung, Y.L.: Stratosphere-troposphere evolution during polar vortex intensification. J. Geophys. Res. 110, D24101 (2005). https://doi.org/10. 1029/2005JD006302

Lozano, R.L., Hernández-Ceballos, M.A., Rodrigo, J.F., San Miguel, E.G., Casas-Ruiz, M., García-Tenorio, R., Bolívar, J.P.: Mesoscale behavior of ${ }^{7} \mathrm{Be}$ and ${ }^{210} \mathrm{~Pb}$ in superficial air along the gulf of Cadiz (south of iberian peninsula). Atmos. Environ. 80, 75-84 (2013). https://doi.org/10.1016/j.atmosenv.2013.07.050

Maenhaut, W., Zoller, W.H., Coles, D.G.: Radionuclides in the south pole atmosphere. J. Geophys. Res. 84, 3131-3138 (1979)

Marenco, A., Fontan, J.: Etude des variations des ${ }^{7} \mathrm{Be},{ }^{32} \mathrm{P},{ }^{90} \mathrm{Sr},{ }^{210} \mathrm{~Pb}$ et ${ }^{210}$ Po dans la troposphere. Tetlus. 26, 386-401 (1974)

Matthews, K.M., Kim, C.K., Martin, P.: Determination of ${ }^{210}$ Po in environmental materials: a review of analytical methodology. Appl. Radiat. Isot. 65(3), 267-279 (2007). https://doi.org/10.1016/j. apradiso.2006.09.005

Mishev, A.L., Kocharov, L.G., Usoskin, I.G.: Analysis of the ground level enhancement on 17 May 2012 using data from the global neutron monitoring network. J. Geophys. Res. Space Physics. 119, 670-679 (2014). https://doi.org/10.1002/2013JA019253

Pan, J.S., Wen, F.P., Chen, L., Ren, X.N., Zhang, J., Zhao, S.P., et al.: Preliminary analysis of activity concentration distributions of airborne ${ }^{210} \mathrm{Po}$ and ${ }^{210} \mathrm{~Pb}$ in major cities in China. Radiation Protection. 37(6), 433-437 (2017)

Papastefanou, C.: Beryllium-7 aerosols in ambient air. Aerosol Air Qual. Res. 9(2), 187-197 (2009). https://doi.org/10.4209/aaqr.2009.01. 0004

Papastefanou, C., Ioannidou, A.: Aerodynamic size association of ${ }^{7} \mathrm{Be}$ in ambient aerosols. J. Environ. Radioact. 26, 273-282 (1995)

Press, W.H., Teukolsky, S.A., Vetterling, W.T., \& Flannery, B.P. (1992). Numerical recipes in Fortran 77, 2nd ed., 933pp, Cambrideg University Press, Cambridge, UK

Rastogi, N., Sarin, M.M.: Atmospheric ${ }^{210} \mathrm{~Pb}$ and ${ }^{7} \mathrm{Be}$ in ambient aerosols over low- and high-latitude sites in semiarid region: temporal 
variability and transport processes. J. Geophys. Res. Atmos. 113(11), 1-14 (2008). https://doi.org/10.1029/2007JD009298

Rehfeld, S., Heimann, M.: Three dimensional atmospheric transport simulation of the radioactive tracers $210 \mathrm{~Pb}, 7 \mathrm{Be}, 10 \mathrm{Be}$, and $90 \mathrm{Sr}$. J. Geophys. Res. 100(D12), 26,141-26,161 (1995)

San Miguel, E.G., Hernández-Ceballos, M.A., García-Mozo, H., Bolívar, J.P.: Evidences of different meteorological patterns governing ${ }^{7} \mathrm{Be}$ and ${ }^{210} \mathrm{~Pb}$ surface levels in the southern Iberian Peninsula. J. Environ. Radioact. 198(December 2018), 1-10 (2019). https://doi. org/10.1016/j.jenvrad.2018.12.007

Stein, A.F., Draxler, R.D., Rolph, G.D., Stunder, B.J.B., Cohen, M.D., Nqan, F.: NOAA's HYSPLIT atmospheric transport and dispersion modeling system. Bull. Am. Meteorol. Soc. 96, 2059-2077 (2016)

Thompson, D.W.J., Lorenz, D.J.: The signature of the annular modes in the tropical troposphere. J. Clim. 17(22), 4330-4342 (2004). https:// doi.org/10.1175/3193.1

Thompson, D.W.J., Wallace, J.M.: The Arctic oscillation signature in the wintertime geopotential height and temperature fields. Geophys. Res. Lett. 25(9), 1297-1300 (1998). https://doi.org/10.1029/ 98GL00950

Thompson, D.W.J., Wallace, J.M.: Annular modes in the extratropical circulation. Part I: month-to-month variability. J. Clim. 13(5), 1000$1016(2000)$

Thompson, D.W.J., Wallace, J.M.: Regional climate impacts of the northern hemisphere annular mode. Science. 293(5527), 85-89 (2001). https://doi.org/10.1126/science.1058958

Thompson, D.W., Wallace, J.M., Hegerl, G.C.: Annual modes in the extratropical circulation. Part II: Trends. J. Clim. 13, 1018-1036 (2000)

Tositti, L., Hübener, S., Kanter, H.J., Ringer, W., Sandrini, S., Tobler, L.: Intercomparison of sampling and measurement of ${ }^{7} \mathrm{Be}$ in air at four high-altitude locations in Europe. Appl. Radiat. Isot. 61, 1497-1502 (2004)

Turekian, K.K., Benninger, L.K., Dion, E.P.: ${ }^{7} \mathrm{Be}$ and ${ }^{210} \mathrm{~Pb}$ total deposition fluxes at New Haven Connecticut and at Bermuda. J. Geophys. Res. 88, 5411-5415 (1983)

UNSCEAR. (2000). Sources and effects of ionizing radiation, United Nations Scientific Committee on the effects of atomic radiation UNSCEAR 2000 report to the general assembly, with scientific annexes. In UNSCEAR 2000 Report: Vol. I

Usoskin, I.G., Kovaltsov, G.A.: Production of cosmogenic ${ }^{7}$ Be isotope in the atmosphere: full 3-D modeling. J. Geophys. Res. Atmos. 113(12), 1-12 (2008). https://doi.org/10.1029/2007JD009725
Visbeck, M.H., Hurrell, J.W., Polvani, L., Cullen, H.M.: The North Atlantic oscillation: past, present, and future. Proc. Natl. Acad. Sci. 98, (2001). https://doi.org/10.1073/pnas.231391598

Wang, K.-Y., Chau, T.-T.: An association between air pollution and daily outpatient visits for respiratory disease in a heavy industry area. PLoS One. 8(10), e75220 (2013). https://doi.org/10.1371/journal. pone.0075220

Wang, K.-Y., Kau, W.S.: Simulation of impact from stratospheric ozone on global tropospheric ozone distribution with a chemistry transport model: a case study during the 1990-1991 period. Asia-Pac. J. Atmos. Sci. 51(2), 137-155 (2015)

Wang, K.-Y., Pyle, J.A., Sanderson, M.G., Bridgeman, C.: Implementation of a convective atmospheric boundary layer scheme in a tropospheric chemistry transport model. J. Geophys. Res. 104(D19), 23,729-23,745 (1999)

Wang, K.-Y., Shallcross, D.E., Pyle, J.A.: Seasonal variations and vertical movement of the tropopause in the UTLS region. Ann. Geophys. 20(6), 871-874 (2002)

WOUDC. (2021). Dataset information: OzoneSonde. Would Ozone and Ultraviolet Radiation Data Centre. https://geo.woudc.org/def/data/ ozone/vertical-ozone-profile/ozonesonde, Version 1.30.0, doi: https://doi.org/10.14287/10000008

Wu, B.Y., Wang, J.: Winter Arctic oscillation, Siberian high and east Asian winter monsoon. Geophys. Res. Lett. 29, 1897 (2002)

Zhang, W., Chen, J., Ungar, K., Cooke, M.: Estimation of the Arctic aerosols from local and long-range transport using relationships between ${ }^{210} \mathrm{~Pb}$ and ${ }^{212} \mathrm{~Pb}$ atmospheric activity concentrations. J. Environ. Radioact. 141, 123-129 (2015)

Zhao, S., Miller, A.J.: The interaction of the madden-Julian oscillation and the Arctic oscillation. J. Clim. 18, 143-159 (2005)

Zheng, X., Wang, G., Tang, J., Zhang, X., Yang, W., Lee, H.N., et al.: ${ }^{7} \mathrm{Be}$ and ${ }^{210} \mathrm{~Pb}$ radioactivity and implications on sources of surface ozone at Mt. Waliguan. Chin. Sci. Bull. 50(2), 167-171 (2005)

Zhou, S., Miller, A.J., Wang, J., Angell, J.K.: Trends of NAO and AO and their associations with stratospheric processes. Geophys. Res. Lett. 28, 4107-4110 (2001)

Publisher's Note Springer Nature remains neutral with regard to jurisdictional claims in published maps and institutional affiliations. 